\title{
The Association of Saint James: a Hebrew-Christian Church in Israel
}

\subsection{Barlassina and Jewish Converts}

The political discord that erupted in the 1950s over the laws governing Christian institutions was just one aspect of a more complex constellation. At its core was the laborious process of building the State of Israel and the unresolved nature of the new state's Jewish character. The subject of conversion from Judaism to Christianity raised the specter of a lurking internal enemy beyond the Palestinian population that remained within Israel's borders.

For various reasons, the Jerusalem Latin diocese was also exercised by the question of conversions from Judaism to Christianity. After 1948, the Catholic hierarchy's opposition to the politics of the Israeli government and its clergy's traditionally anti-Jewish sentiments made relationships increasingly difficult between the Arab-majority community of faithful and the part of the Catholic congregation that was Jewish in origin. Immigrants to Palestine who arrived after fleeing years of Nazi-Fascist antisemitic persecution and extermination included individuals and families of Jewish origin who had converted to Christianity long ago, the offspring of mixed marriages as well as those who embraced the Christian faith after their arrival. Precise information on their number was difficult to obtain, although the Latin Patriarchate estimates that in the mid-195os it included between two thousand and four thousand people, mostly represented by Catholics married to Jews and only some hundred converts. ${ }^{1}$ The milestone of the foundation of the State of Israel and the demographic, social and economic transformations this then imposed on the administration and pastoral work of the local Christian churches represent central events in the life of the Christian world of Jerusalem and of the wider region. Thus, for the church, the 1950s marked the beginning of a long and tortuous path to the recognition of the Jewish converts within the Latin patriarchal diocese.

1 See APNDS, P. Stiassny, minutes of the meeting of the Association of Saint James, November $11-12,1955$. 
Historically, pastoral attention to the Jewish world had been central to the missionary activities of various Christian congregations and denominations both Catholic and Protestant - that began to arrive in Palestine at the beginning of the nineteenth century. Protestants were most active among these groups: several evangelical environments, especially in Britain, saw millennial hopes and expectations combining to invest Palestine with a new level of importance. ${ }^{2}$ Although a tiny fraction compared to the Protestant initiatives, there was also a millennarianist strain within Catholicism, mostly influenced by Jansenism, that embedded itself in eighteenth-century pro-Judaism and continued to take hold in the nineteenth century. ${ }^{3}$ Some watershed events in the history of Europe - chief among them the French Revolution - were interpreted as signs of the imminent return of Christ. Within this frame of reference, the conversion of the Jews and their return to Palestine were reimagined as phenomena that would accelerate the impending manifestation of Christ and the end of days. This consideration put proselytism at the center of missionary attention in various congregations, especially British ones, notably the London Society for Promoting Christianity Amongst the Jews, also called the London Jews' Society, founded in 1809 .

Within a context of the arrival of numerous missionaries to Palestine in the decades that followed, the foundation of the Protestant diocese of Jerusalem in 1841, on a joint Prussian and British initiative, was a remarkable event. The goals of the episcopal see included as a primary objective an apostolate to convert Jews, as exemplified by the action undertaken by the first Protestant bishop of Jerusalem, Michael Alexander - himself a converted Jew - and his successor, Samuel Gobat. The new diocese built hospitals and schools and provided employment; these institutions were intended, first, to create a point of contact with the Jewish population that would be conducive to their conversion and to the instruction of neophytes; and second, the evangelical organizations were intended to respond to requests for work from those who had converted from Judaism to Christianity. The opposition to Christian proselytism contributed to the converts' isolation - not only individually and socially but also

2 For a characterization of Christian millenarianism and its repercussions for the Jews, see Sarah Kochav, "Beginning at Jerusalem': The Mission to the Jews and English Evangelical Eschatology," in Jerusalem in the Mind of the Western World, 1800-1948, ed. Yehoshua BenArieh and Moshe Davis (Westport, CT: Praeger, 1997); Stephen Orchard, "Evangelical Eschatology and the Missionary Awakening," Journal of Religious History 22, no. 2 (1998); and Mayir Vreté, "The Restoration of the Jews in English Protestant Thought, 179o-1840," Middle Eastern Studies 8, no. 1 (1972).

3 See Véronique Alemany, La dernière solitaire de Port-Royal: Survivances jansénistes jusqu'au $X X^{e}$ siècle (Paris: Cerf, 2013). 
economically - with respect to their community of origin. Consequently, these neophytes did not preach their new Christian faith to their families. Despite the fact it became ever more structured, the Protestant proselytism effort among the Jews of the region did not achieve particularly significant results. Bishop Gobat's efforts to convert the Jews progressively dissipated, to be replaced by those of other Christian denominations, particularly the Latin Catholics. ${ }^{4}$

The emergence of the Zionist movement represents a major turn in this story. From the second half of the nineteenth century, for some millennarianist Protestants, belief in the imminent return of Christ and consequent necessity for the rapid conversion of the Jews in Palestine was galvanized by their embrace of Zionism, which was seen as a movement that would enable the return of the Jews to the Holy Land. These two aspects combined to produce the Christian support for the Zionist cause that began to develop during this period. ${ }^{5}$

As for the attitude of the Catholics in Palestine regarding the question of proselytism and the conversion of Jews to Christianity, the pastoral care of converts was not the subject of a specific and coherent action by the patriarchate for several decades after the reconstitution of the Latin diocese. The information as to who the catechumens were, who dealt with them, and according to what pastoral lines is scant. The correspondence between the patriarchate and the Congregation for the Propagation of the Faith does include some references to Jews seeking conversion, especially in the context of disputes over marriage dispensations. ${ }^{6}$

4 See Heleen L. Murre-van den Berg, "'Simply by giving to them maccaroni ...': Anti-Roman Catholic Polemics in Early Protestant Missions in the Middle East, 1820-186o," in Christian Witness Between Continuity and New Beginnings: Modern Historical Missions in the Middle East, ed. Martin Tamcke and Michael Marten (Münster: LIT, 2006); and Thomas F. Stransky, "La concurrence des missions chrétiennes en Terre Sainte, 1840-1850," trans. Dominique Trimbur, in eds. Aaronsohn and Trimbur, De Bonaparte à Balfour.

5 The history of Christian Zionism has not yet been comprehensively studied, although the subject constantly draws major attention in the media and political rhetoric, fueled by ideological interpretations. For an outline of the fundamental features of the phenomenon, see Donald M. Lewis, The Origins of Christian Zionism: Lord Shaftesbury and Evangelical Support for a Jewish Homeland (Cambridge: Cambridge University Press, 2010); Shalom Goldman, Zeal for Zion: Christians, Jews, and the Idea of the Promised Land (Chapel Hill: University of North Carolina Press, 2009), and Paul C. Merkley, The Politics of Christian Zionism, 1891-1948 (London: Frank Cass, 1998).

6 ACo, Latini, Delegazione Apostolica Palestina: affari generali, 446, Dispense matrimoniali, 1923-1928. In ACPF see also "one such Jew, Leone Spire, born in Jerusalem, who has traveled through large parts of Asia, Africa, and Europa ... in order not only to be baptized, but also taken on as a missionary" a few years before the reestablishment of the patriarchate. Vol. 18, 
In 1908 Patriarch Filippo Camassei established the Association of Prayers for Israel, placing the community under the superior of the Fathers of Sion in Paris. Its goal was to pray for the conversion of Jews to the "unity of the Catholic

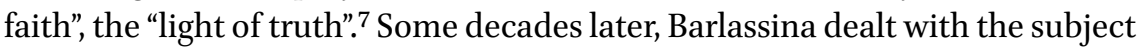
of the pastoral to converted Jews. In a letter to Apostolic Delegation Regent Hughes, the patriarch referred to the case of a Romanian called Talvy, "a converted Jew of about twenty years' standing", praising him for "the intense and efficacious apostolate he performs to the Jews and intellectual Protestants". Barlassina's words make clear, first, that in postulating the essential traits of long-term adherence to Catholicism, he characterizes the neophyte as someone who should work particularly diligently to convert his community of origin. Second, however, he expresses his wish that the converted Jew's activity should not be limited only to his former coreligionists but should also be directed at non-Catholic Christians, specifically Protestants.

Later, pastors wrote to the patriarch asking how they should behave toward Jews who approached them seeking to receive the sacraments. In response to a direct request to Barlassina from an Italian Jew in Palestine, Adolfo Levi, who wished "to receive instruction to become a Christian", the patriarch asked the curate of Jaffa to deal with the matter. In so doing, he emphasized the necessity for the Christian education of catechumens to be "firm and deep", imparted over "several months"; it was important "to habituate him to Christian practice immediately, especially as regards the intentions of his actions and his inner life". ${ }^{9}$ Furthermore and significantly, Barlassina conceived the foundation of a religious congregation, the Ancelles de Notre-Dame de Palestine (Handmaids of Our Lady Queen of Palestine), whose conversionist intent was to be dedicated to the "truly missionary and apostolic work ... especially to the Jews and Muslims, where a most promising field is opening up". ${ }^{10}$ Barlassina asked the

fols. 553-54, Auditor of Nunciature Gaetano Bedini to Propaganda Fide, Vienna, July 31, 1841 , translation from Italian.

7 APNDS, Annales 120, "Statuts de la confrérie," 1908. On the history of this Brotherhood, see Olivier Rota, "L'association de Prières pour Israël (1903-1966): une association révélatrice des orientations orthodoxes de l'Église face aux Juifs," Bulletin du Centre de recherche français à Jérusalem 13 (2003).

8 APLJ, LB-AG, Délégué Apostolique, 1943-1955, Barlassina to Hughes, copy, Jerusalem, undated (ca. summer 1946), translation from Italian.

9 APLJ, Paroisses, Jaffa, 1950-, Barlassina to Stellacci, copy, Jerusalem, January 2, 1947.

10 "Since Providence sent me there, I have always bemoaned a deep rift; although there are many communities that, to a greater or lesser extent, receive some of those who request admission to Catholicism, no one has thought to go out and look for them. Meanwhile, the Protestants unleash their deaconesses and ministers all over the region and proselytize greatly; should we alone stand aside, yielding up a position that was entrusted to 
Sisters of Notre-Dame de Sion to include the Ancelles within their congregation and an agreement was reached in $1936 .{ }^{11}$

In 1945, following Barlassina's request for a catechism for Jewish converts, the Franciscan Printing Press published Or va-Osher (Light and happiness). The authors were only identified by their initials (A.M., D.G., V [ve in Hebrew] and M.V.), but it is possible that these letters stand for the Catholic motto "Ad Maiorem Dei Gloriam et Mariae Virginis", representing an attempt to avoid censorship, preserve the complete anonymity of the author and hint at the imprimatur of the Latin Patriarch. The author was most likely Jean-Marie Paul Bauchet, who, after gaining a solid foundation in Hebraic studies in France and Iraq, moved to Jerusalem in 1941 and took up studies at the Hebrew University. The 36o-page catechism was written in modern Hebrew, with parts in Latin, Greek, German, French, Italian and, in three final pages, Arabic, and included Bible extracts, prayers, theological explications and articles from the contemporary German, Italian and French press. Tisserant followed the writing of this work, corresponding with Bauchet and directly reported to Pius XII. ${ }^{12}$ Bauchet would write some other books in Hebrew: in 1946 he anonymously published a 55-page prayer book and a 71-page book on the life of Saint Francis. ${ }^{13}$ Just before the outbreak of the Palestine War, the Apostolic Delegation proposed to entrust Bauchet with the care of converted Jews, but this idea, supported also by the rector of the Pontifical Biblical Institute in Rome, Augustin Bea, was then abandoned. ${ }^{14}$

the Holy Gospel?" Aco, Latini, Patriarcato Latino, Propaganda Fide, 493, Barlassina to Cardinal Willem van Rossum, May 12, 1930, translation from Italian. On the history of this congregation, see Olivier Rota, Apostolat catholique et travail social en milieu juif: Les Ancelles de Notre-Dame de Sion (1926-1964) (Paris: Cerf, 2019); Paule Marx, "Les Ancelles à la recherche d'une modalité de présence chrétienne en milieu juif," Sens 410 (JanuaryFebruary 2017); and Sanchez Summerer, "Ouvrir les trésors de la charité aux enfants dévoyés d'Abraham."

11 ASNDS, Ancelles, "Per Mariam ad Jesum," copy, undated.

12 ACo, Latini, Palestina e Transgiordania: Patriarcato di Gerusalemme, 855/49, 1, doc. 10, "Per l'udienza del Santo Padre". Tisserant annotated by hand that the pope wanted the book to be examined by a competent person before publication. The secretary of the Oriental Congregation proposed Jean de Menasce.

13 Liber Precum in honorem Sancti Francisci (Jerusalem: Franciscan Printing Press, 1946) and Gephen Poriyah: Divre ha-Yamim shel ha-Frantsiskanim va Kitsur shel Hayye Frantsiskus ha-Kadosh [Fruitful vine: a summary of the life of Saint Francis and of the history of the Franciscans] (Jerusalem: Franciscan Printing Press, 1946). Both the books have the same official ecclesiastical approval dates: March 13, 1946, for the patriarch's imprimatur and March 22, 1946, for the custos's nihil obstat.

14 "Whatever the future political situation of Palestine will be, the Church will face hundreds of thousands of Jews to whom it will have to stretch out its maternal arms to welcome 
The foundation of the State of Israel in 1948 and the nomination of Alberto Gori as Latin patriarch a year later do not seem to have brought much change to the pastoral care of converted Jews on the part of the patriarchate. However, Rome, especially the Congregation for the Oriental Church and its secretary, Eugène Tisserant, highlighted Jerusalem's apparent immobility with respect to these issues.

\section{$1.2 \quad$ Tisserant's Concerns}

Tisserant was particularly attentive to events surrounding the foundation of the State of Israel. From 1948, he established contacts with several important international representatives of the Jewish world and of the Israeli government. In a phase of extremely critical relations between the Holy See and Israel, Tisserant was Rome's principal communicator of the Israeli government's positions. And his attentiveness to Middle Eastern affairs was not limited to religious and political questions. Deeply versed in Semitic languages and cultures, the French cardinal maintained direct contact with Jewish intellectuals. He monitored the Middle East closely, convinced that the clash of the three great monotheistic religions in the region could lead to the triumph of atheistic communism. ${ }^{15}$

Within this highly complex picture, the question of converted Jews seemed particularly relevant to Tisserant. In his reading of events, in the post-1948 scenario these people could represent a cohesive force between the Arab Christian community and Jewish society, as well as initiate action for the apostolate within the State of Israel after decades of nonintervention. Furthermore, the creation of a Catholic community of converted Jews constituted an effective example of Jewish-Catholic dialogue in the period after the Shoah, when signs of innovation and revision began to emerge from a long tradition of hostility and conflict.

Tisserant was not alone in attributing an important role to converts from Judaism on the rocky path that bridged these two worlds. Historically, not only had these converts been a proselytizing force - as in the case of the neophytes

them into the truth and redemption. So far, unfortunately, it must be confessed, little or nothing has been done in this sense in Palestine by the Catholic side ... The person of the Rev. Fr. Paul de Jésus et Marie is truly the most suitable religious - not to mention the only one - who, animated by a true sense of Christian charity and knowing not only the modern language but also the serious spiritual problems facing by so many good Jews, could direct this new form of active apostolate." ACO, Latini, Palestina e Transgiordania: Patriarcato di Gerusalemme, 855/49, 1, doc. 45, Apostolic Delegation to the Oriental Congregation, attachment A, July 14, 1947, translation from Italian.

See Fouilloux, Eugène, cardinal Tisserant, 421-54. 
within the homes of catechumens - they had also been the mouthpiece for a different consideration, inspired by greater charity and fraternity toward the Jews on the part of the church. But it was precisely for this reason that the converts were viewed with suspicion by various fundamentalist Catholic groups. For example, Cardinal Rafael Merry del Val, secretary of the Congregation of the Holy Office, denounced the Amici Israel (Friends of Israel) society, formed in the 1920 s to promote an innovative apostolate to Israel within the Roman Catholic church, although without completely abandoning the intent to convert, as a cover for a movement that intended to overthrow not only the secular order - following the Jewish conspiracy topos - but also the church itself, from within. ${ }^{16}$ Clearly, this type of historical precedent could hamper the inauguration of new basis for dialogue.

However, these considerations did not prevent the opening up of new spaces of encounter between Jews and Christians after the Second World War. One of the most significant of these opportunities was the Seelisberg Conference. Organized on the instigation of the International Council of Christians and Jews in the Swiss town of Seelisberg, the meeting, which was held in the summer of 1947, brought some seventy Jewish and Christian (both Protestant and Catholic) participants together to confront the origins of Christian antisemitism and to discuss means to counter it. ${ }^{17}$ Jules Isaac headed the Jewish members, while Catholic representatives included Charles Journet, ${ }^{18}$ Paul Démann ${ }^{19}$

16 See Wolf, Pope and Devil, 106-7.

17 For an analysis of the Seelisberg Conference and the role of Jules Isaac within it, see Norman C. Tobias, Jewish Conscience of the Church: Jules Isaac and the Second Vatican Council (Cham: Palgrave Macmillan, 2017), 104-17.

18 A Swiss Catholic theologian, Charles Journet (1891-1975) dedicated much of his life to the teaching of dogmatic theology. Attentive to Jewish-Christian relationships and a friend of Maritain, he was the author of the important volume Destinées d'Israël: A propos du Salut par le Juifs (Paris: Egloff, 1945). In 1965, Paul vi made him a cardinal, and he participated in the Second Vatican Council.

19 Originally from a Hungarian Jewish family, Paul Démann (1907-2005) converted to Christianity in the 1930s and became a priest in 1944, joining the order of Notre-Dame de Sion. During the war, he pledged to save some Jews, and after the end of the conflict he created the Cahiers sioniens (1947-55), a magazine aimed at expanding the dialogue between Christians and Jews. He participated in the Seelisberg Conference. He left the congregation in the 196os but remained one of the protagonists for the new course of contact between Jews and Christians after the Second Vatican Council. His most important work is Les Juifs: Foi et destinée (Paris: Fayard, 1961). For a short overview of Démann's importance in Jewish-Christian dialogue, see Olivier Rota, "Dépasser les cadres du philosémitisme: La vision œcuménique de Paul Démann," Archives juives 40, no. 1 (2007). 
and Jean de Menasce. ${ }^{20}$ At the end of the conference, a document was ratified for presentation to the church that outlined the ten points presented by Isaac during the meeting. ${ }^{21}$ The concluding text of the meeting also contained the reflections of Jacques Maritain, who - although unable to attend - had sent a letter to the conference secretary, Pierre Visseur, in which he expressed his fears of a rekindling of antisemitism in Europe and his proposals for a new course for Jews and Christians.

In Rome, Tisserant was in contact with some of the promoters of the Seelisberg Conference. He also followed the activities of Jewish-Christian friendship associations that were springing up in France (one came into existence in Paris in 1948), Switzerland and the Netherlands. In this context, he began to pose the question of dedicated pastoral care for the Jewish world and in the State of Israel on the part of the patriarchate, the custody, and other historically important religious congregations. Since the establishment of the Apostolic Delegation and Gori's elevation to the patriarchate, Tisserant hoped to see these issues addressed by the apostolic delegate and the former custos. ${ }^{22}$ The secretary of the Oriental Congregation admitted that he had received complaints from baptized Jews originally from Eastern Europe, especially Bulgaria and Hungary, that there were no priests in Israel they could turn to for spiritual services. Tisserant suggested that the patriarch should request the help of the Assumptionists, requesting that their superior general commission

20 From a Jewish family of Egyptian origin, Jean de Menasce (1902-73) converted to Christianity and entered the Dominicans. He took part in the Seelisberg Conference and committed himself to Jewish-Christian dialogue. A student of Chassidism and an ardent philo-Zionist, he was the author of an important work titled Quand Israël aime Dieu (Paris: Plon, 1931). See Michel Dousse and Jean-Michel Roessli, Jean de Menasce (19021973) (Fribourg: Bibliothèque cantonale et universitaire, 1998).

21 Jules Isaac (1877-1963) was born into a Jewish family in Lorraine. He studied modern history at the Sorbonne and worked as a history teacher until the Second World War, when he left Paris for the south of France. He lost his wife and children in Auschwitz. The tragedy of the Shoah drove him to ask himself how it was possible for Christian Europe to become a theater for the extermination of the Jewish people. In 1948, he published Jésus et Israël, which would become profoundly important in the history of Jewish-Christian relations. In the book, Isaac lays out his thesis, based on the conviction that there was an enormous gap between the manner in which the New Testament was presented to the Jews and the subsequent teaching of the church, which was hostile to the Jews (what Isaac called the "teaching of contempt" (l'enseignement du mépris), which became the title of a work he published in 1962. See Tobias, Jewish Conscience of the Church; André Kaspi, Jules Isaac: Historien, acteur du rapprochement judéo-chrétien (Paris: Plon, 2002).

Tisserant listed the "apostolate for the conversion of the Jews" among the first "most serious questions" for Testa's charge after his appointment as apostolic delegate in Jerusalem, Palestine, Transjordan and Cyprus. See AAV, ADAGP, 12, 52, 2, fol. 4, Tisserant to Testa, Rome, April 26, 1948, translation from Italian, and fols. 5-13, "Istruzioni per S.E. Mons. Gustavo Testa, Delegato Apostolico della Palestina". 
a clergyman who spoke Bulgarian to "make inquiries of the baptized". ${ }^{23}$ For Tisserant, providing religious care to Jewish catechumens or Jews who had already been baptized and desired "to conserve their character as Christians" was an "absolute duty", but he conceded that this obligation was not easy to fulfill.

The French cardinal formulated a concrete proposal to "create a center for those converts, not by any means to group them all together, but to provide a basis for an official organization". ${ }^{24} \mathrm{He}$ hereby intended to engage diverse religious actors: not only the patriarchate, but also the custody and other religious congregations, particularly clergy who historically had close relations with the Jewish world. The importance of bringing linguistic competence to bear alongside various pastoral sensitivities necessitated the creation of a network of figures and institutions within the Latin Church dedicated to these purposes. Ultimately, the pastoral care in Israel and to Israel required the development of a new attitude, a different view on the part of the Catholic world, to overcome the traditional hostility toward the Jewish world as well as the previous patterns of philosemitism. ${ }^{25}$

Tisserant's proposal was probably influenced by the exchanges he had with Paul Démann. The Father of Sion had sent Tisserant a report written by two young converted Jews, Renée Bloch ${ }^{26}$ and Myriam Kleinberger, ${ }^{27}$ who had been helping him in his cultural and pastoral work over the previous two years. In the summer of 1950 they spent some months in Israel in order to commence apostolate activity. They traveled the country, where they had contact with some

23 APLJ, FC-AG, S. Congregatio Pro E. Orientali, 1919-1953, Tisserant to Gori, Rome, August 29, 1950, translation from Italian.

24 Ibid.

25 See Jean Dujardin, L'Eglise catholique et le peuplejuif: Un autre regard (Paris: Calmann-Lévy, 2003). On philosemitism, see Olivier Rota, Essai sur le philosémitisme catholique entre le premier et le second Vatican: Un parcours dans la modernité chrétienne (Arras: Artois Presses Université, 2012), and especially, for the material central to the present study, 181261. See also Jonathan Karp and Adam Sutcliffe, eds., Philosemitism in History (Cambridge: Cambridge University Press, 2011), and William D. Rubinstein and Hilary L. Rubinstein, eds., Philosemitism: Admiration and Support in the English-Speaking World for Jews, 18401939 (Basingstoke: Macmillan, 1999).

26 Renée Bloch (1924-55), who converted when she was seventeen years old, was a brilliant student of theology and Semitic languages in Paris. After meeting Démann, she wrote for and edited the Cahiers Sioniens, publishing pioneering articles on the history and meaning of the midrash, before her tragic death when El Al Flight 402 was shot down by the Bulgarian air force on July 27, 1955 .

27 Born into a Belgian Jewish family, during the Second World War she was rescued by nuns. In the 1950s she entered the community of the Little Sisters of Jesus and moved to Israel, where she spent the rest of her life. 
Catholic representatives, notably Georges Hakim. At the end of their journey, the Melkite bishop wrote to Tisserant to propose that he grant an audience to the two women. ${ }^{28}$ At the meeting, the two women made a very good impression on the cardinal ("they are two converts of excellent spirit and zeal"), ${ }^{29}$ who asked them to submit a report on their opinions and ideas on the role of the Catholic Church in Israel. They sent the document via Démann in late August. In their lucid text, they described the Jerusalem Catholic Church as an "unadapted Church", incapable of dealing with the new situation presented by the 1948 war and the establishment of the Israeli state. ${ }^{30}$ In this situation, the church could choose between "an effort of reorientation and adaptation" or "a sterile regard for a past that will never return". To renew the Jerusalem Church, Bloch and Kleinberger recommended the foundation of a new community of "apostles, priests and laity" for the converted Jews and for the opening of a new dialogue between Catholics and Jews. They proposed to create "a small group, next year, in Tel Aviv", with some converted Jewish girls they frequented during their journey. In Bloch and Kleinberger's view, this presence should maintain discretion and not at all be oriented to proselytism. To prepare this apostolate, the two women planned to study modern Hebrew, Judaism and theology for one year before their departure.

This document impressed Tisserant and influenced his thought. Thus, two young women - lay, converted Jews - participated in the very first steps of what would have become the Association of Saint James.

\subsection{The Custody's Intervention and Gori's Fears}

In addition to Tisserant's requests, the custody discussed appeals from other clergy who had taken steps to meet with and follow catechumens and Christians of Jewish origin in Israel. In November 1950, the Franciscan minister general, Pacifico Perantoni, wrote to the custos of the Holy Land, Giacinto Faccio, to report on a visit he had received from three priests, "converted Jews, one of them a Father of Sion, one an Assumptionist, and the third a Benedictine - there was also a Dominican priest - who requested our collaboration, the Franciscans in Palestine, to convert the Jews". ${ }^{31}$ The priests asked the custos to assign "two fathers, or even three, from among the clergy of the custody ... willing and able to collaborate in this way", with the ancillary goal

\footnotetext{
28 See ACO, Melchiti, Haifa, 151/50, 4, doc. 95, Hakim to Tisserant, Haifa, August 10, 195 o.

29 Ibid., handwritten note by Tisserant to Hakim's letter.

30 ACO, Latini, Palestina e Transgiordania: affarigenerali, 457/48, 4, doc. 221, "Enquête sur les problèmes chrétiens en Israël," Paris, August 28, 1950, translation from French.

31 ACgofm, Segreteria Generale, Custodia di Terra Santa, 762, doc. 85, Perantoni to Faccio, November 10, 1950, translation from Italian.
} 
of forming an association in Jerusalem, which Perantoni dubbed a "laudable initiative". ${ }^{2}$

It is most likely that the priests Perantoni referred to were Démann and the Assumptionist Jean-Roger Héné, ${ }^{33}$ the Benedictine Leo Rudloff ${ }^{34}$ and the Dominican Jean de Menasce. The fact that Perantoni described the proposal as dedicated to the "conversion of the Jews" and judged it "laudable" casts some doubt on his understanding of the project formulated by these clerics, whose positions and aspirations were not geared toward proselytism but rather the creation of an opening to the Jewish world in Israel and a change in the relationship between Arab Christians and Jewish Christians. Furthermore, Perantoni proposed to Faccio the possibility of sending to Israel Laetus Himmelreich, a Dutch friar and important name in the recent history of relations between Catholics and Jews: ${ }^{35}$ he was among the founders of the Amici Israel society.

The society's project also included the request to reform the Good Friday prayer for the Jews (the "oremus et pro perfidis iudaeis"), eliminating the reference to the "perfidis judaeis" and to "judaicam perfidiam" ("perfidious Jews", "Jewish perfidy"). In February 1928, Himmelreich was to have presented the proposal to reform the antisemitic elements of the Good Friday liturgy at a meeting of the society. But Cardinal Merry del Val - who had originally joined the group in the belief that it was a proselytism effort aimed at the Jews, prohibited the meeting from taking place; once had he understood the various intentions of the Amici Israel, he withdrew from it. ${ }^{36} \mathrm{~A}$ decree issued by the

$32 \quad$ Ibid.

33 Son of an Alsatian Protestant father and a German Jewish mother, Jean-Roger Héné (1918-79) studied in the United States and in France, where he embraced Christianity and entered the Assumptionists during the Second World War. During the Vichy regime, he worked to bring Jewish civilians to safety. A few years after his ordination, in $195^{2}$ he was sent to Israel, where he became one of the founding figures of the AsJ.

34 Leo Rudloff (1902-82), originally from a German Jewish family, converted to Christianity and became a Benedictine monk. He became prior of the Abbey on Mount Zion and a protagonist of the series of Jewish-Christian dialogues that culminated in the Second Vatican Council declaration Nostra Aetate. Together with Démann, he also participated in the meetings in the Dutch city of Apeldoorn in $195^{8}$ and 1960 to prepare the De Iudaeis document.

35 On Himmelreich, see Marcel Poorthuis and Theo Salemink, "Laetus Himmelreich OFM (1886-1957): Zwischen München, Jerusalem und Dachau," in Widerstand Martyrium - Erinnerung: Franziskanische Reaktionen auf den Nationalsozialismus, ed. Michaela Sohn-Kronthaler, Paul Zahner and Eduard Prenga (Innsbruck: Tyrolia, 2017), and Poorthuis and Salemink, "Chiliasme, anti-judaïsme en antisémitisme: Laetus Himmelreich ofm (1886-1957)," Trajecta 9, no. 1 (2000).

36 On this episode, see Renato Moro, "Chiesa e antisemitismo," in Riccardi, Le Chiese e gli altri, 42, and Wolf, Pope and Devil, 101-2. 
Holy Office on March 25, 1928, dissolved the priestly union. Himmelreich resisted the decision but was unable to overturn it. ${ }^{37}$ During the Second World War, the Dutch priest was interned in Dachau concentration camp. At the end of the war, he returned to the Netherlands, where he expressed to his superiors his desire to leave for Palestine, an intention that was redoubled with the founding of the State of Israel. However, Perantoni did not mention Himmelreich's connection to Amici Israel in his letter to the custos, far less the sympathies expressed by the Franciscan and other members of the group for the Zionist project.

In this scenario, with several religious converts from Judaism making requests and Tisserant committed to seeing the Latin Church in Israel guarantee spiritual guidance to converted Jews and catechumens, Custos Faccio's response brought things to a halt. He considered it an impossibility to open up a space for this kind of pastoral provision in Israel, maintaining that the lack of religious freedom in Israel did the most harm to converted Jews, not the lack of pastoral care or any prejudice coming from the church. ${ }^{38}$ However, the custos's response was not exhaustive; he failed to specify which pastoral modalities would be used to realize the apostolate performed by the priests he mentioned, and he did not clarify any guidelines and directives, if indeed these existed.

Faced with this resistance from Faccio, Tisserant decided to take the situation in hand and directly proposed a priest to attend to the question of Jewish converts to Catholicism. This time too, the nominee was Himmelreich, whom Perantoni had advocated two years previously. But the provincial father of the Netherlands and the secretary general to the missions rejected the assignment of the Dutch priest to the monasteries of Tiberias or Mount Tabor to supervise the care of converted Jews and catechumens. And in any case, any definitive decision to assign Himmelreich to Israel would not have spelled the

37 See Theo Salemink, "Cardinal Willem van Rossum and Amici Israel (1926-1928): The Conversion of Jews and the Debate on Zionism," Trajecta 19-20, nos. 1-2 (2010-11); and Menahem Macina, "Essai d'élucidation des causes et circonstances de l'abolition, par le Saint-Office, de l"Opus sacerdotale Amici Israel' (1926-1928)," in Juifs et chrétiens: Entre ignorance, hostilité et rapprochement (1898-1998), ed. Annette Becker, Danielle Delmaire and Frédéric Gugelot (Villeneuve d'Ascq: Université Charles-de-Gaulle-Lille 3, 2002).

38 "There is no real and true freedom of religion in the State of Israel. The converted Jews refuse to declare themselves as such for fear of oppression by fanatics ... It has been reported to me that a rumor has reached Rome that the Catholic priests despise the converted Jews. If 'Catholic priests' refers to the Franciscans, I declare that this rumor is absolute slander." Faccio's sentiments are contained in a letter addressed by the minister general Augustin Sepinski to Tisserant, dated December 20, 1951, contained in ACGOFM, Segreteria Generale, Custodia di Terra Santa, 762, doc. 49, translation from Italian. 
end of the discussion about the spiritual support for the Jews. The Franciscan visitor Barthélemy Héroux, having seen the custody's monasteries from the inside within the new state, expressed the conviction that undertaking this task should not be postponed any longer, citing the importance of a "wholesome proselytism". ${ }^{39}$ Héroux did not specify what he meant by this term; perhaps he believed that the friars should refrain from forced conversions, which after all were impossible to execute in a state where the majority of the population was of the Jewish religion and which defined itself as Jewish. Or that they should operate an intensive apostolate which favored conversion. What guidelines could steer priests in approaching Jews? What differences should there be in how the apostolate treated catechumens and those who had already converted? And most important of all: should the church take steps to encourage conversion or just deal with those who approached the parishes and convents of their own free will? And how could all this be translated into concrete action? There were no answers, which itself was a further sign of how difficult it was to develop a shared vision on the spiritual care of converted Jews and catechumens. Conversely, the deep-seated differences among the various protagonists of this debate began to be more clearly defined: the clergy of Jewish origin - who had initially turned to Perantoni to address these issues - were motivated by a rejection of conversionist activity and the desire for a redefinition of the relationship between Catholics and Jews that would overcome the traditional hostility, motivations that Tisserant shared in large part. Custody representatives ascribed a positive, missionary connotation to the term apostolate, unaccompanied by coercive measures: this was where some, like Héroux and Faccio, could hope for the reinforcement of a "wholesome proselytism" by the Catholics in Israel. However, this second position, which was historically closer to the Catholic tradition of being a force for converting Jews, appeared in a rather nuanced and shaded form. ${ }^{40}$ As it turns out, Faccio does not seem to have discussed anything to do with the pastoral praxis current among the Franciscans in Israel, while Héroux recognized the necessity to train the clergy to be open to a new way of considering the Jews, their

39 ACGOFM, ibid., 764, doc. 25, Héroux to Sepinski, Jerusalem, April 23, 1953, translation from Italian.

40 In the vast historiography on conversions from Judaism to Christianity, see Marina Caffiero, Forced Baptisms: Histories of Jews, Christians, and Converts in Papal Rome, trans. Lydia G. Cochrane (Berkeley: University of California Press, 2012); Fausto Parente, Les Juifs et l'Eglise romaine à l'époque moderne ( $X V^{e}-X V I I I{ }^{e}$ siècles) (Paris: Honoré Champion, 2007). For the present topics, see esp.John Connelly, From Enemy to Brother:The Revolution in Catholic Teaching on the Jews, 1933-1965 (Cambridge, MA: Harvard University Press, 2012). 
history, culture and religion, acknowledging the entrenched hostility among Catholics and highlighting the urgent need to eradicate it. ${ }^{41}$ Thus, Héroux openly supported the need to assign a prominent place to the pastoral care of the Jews because "the time has come, or rather we are coming late to organizing an effective apostolate, since other orders have already done more work than we have. It would be a true sin to pass up these times that seem to be the hour of grace for this people, according to the view of the experts." ${ }^{2}$ The "hour of grace", which was not specified, was perhaps a vague reference to the connected idea of the identification of the foundation of the State of Israel with the Jews' "return to Zion" which would have prefigured and accelerated their conversion, a vision shared - so it seems - in various Christian contexts, especially within Protestant denominations. However, this conviction did not meet with the agreement of many Roman Catholic priests in the region; in any case, Héroux expressed himself in an ambiguous manner, perhaps in order to supply additional arguments in support of placing this pastoral care in the hands of some of the friars.

If opinions differed within the custody and, in any case, remained vague and sketchily demarcated, within the patriarchate the predominant response was silence. Patriarch Gori was conscious of the need to address the question of the converted Jews, and he had been discussing it with Tisserant at the time of his appointment as Latin patriarch. On these matters, the key word at the patriarchate was "prudence". ${ }^{43}$ Regarding the Jewish Christians, Gori proposed a threefold distinction: Christians married to Jews, converted Jews, and Jews who intended to convert - three categories of very different proportions, motivations and pastoral care from the patriarchate. The patriarch's wording was characterized by vagueness too, however. By late spring 1953, at least, the patriarch did not seem to have had any plans to handle the situation of the catechumens and converts.

41 "Several clergy have little sympathy for the Jews; some of them, besides nurturing such sentiments, are not afraid to express them in public ... This attitude ... seems to me absolutely improper for the missionary state ... It seems to me that all the clergy who do not sympathize with the State of Israel and the Jews should be transferred elsewhere." ACGOFM, Segreteria Generale, Custodia di Terra Santa, 764, doc. 25, Héroux to Sepinski, Jerusalem, April 23, 1953 .

42 Ibid.

43 ACO, Latini, Palestina e Transgiordania: Patriarcato di Gerusalemme, 858/49, 2, doc. 111, "Memorandum circa lo stato dei Cristiani e dei Cattolici in Israele," Rome, October 27, 1950, translation from Italian. In APLJ, FC-AG, S. Congregatio Pro E. Orientali, 1919-1953, the typescript draft reports Gori's manuscript notes. 


\subsection{The First Protagonists}

Given the lack of direction, some religious clergy (close to those who went to Perantoni in 1950) now resolved to take action autonomously from the Catholic Church, albeit in contact with the apostolic delegate to Jerusalem, Gustavo Testa, and the Vatican dicastery for the Oriental Church. These were mostly Assumptionists, Dominicans, Notre-Dame de Sion clergy and Carmelites. The main protagonists of the community that would be approved as the Association of Saint James (ASJ) were the priests Joseph Stiassny, ${ }^{44}$ Jean-Roger Héné and Bruno Hussar. ${ }^{45}$ To understand their work, it is important to appreciate the environments from which they originated.

The cultural premises of the ASJ are evident in the relationship between the Catholic and Jewish worlds in the aftermath of the Second World War. Discussion of the Catholic role in the antisemitic extermination and affirmation of the need to reconsider the church's attitude toward the Jews comprised the fundamental points of alignment for a composite movement comprised of diverse components and institutions. Some, like Paul Démann, founder of the Cahiers sioniens (1947), were primarily motivated by the desire to kindle an internal Catholic debate on these issues which should involve important personalities in the church hierarchy such as Tisserant. Furthermore, driven by Jules Isaac's reflections and initiatives to inaugurate a new era of dialogue between Jews and Christians, the Amitiés judéo-chrétiennes (Judeo-Christian Friendships) came into being in 1948 at the behest both of Isaac himself and of the bishop of Aix-en-Provence, Charles de Provenchères. ${ }^{46} \mathrm{~A}$ third factor involved a heuristic drive toward the renewal of theological studies, including reflection on Catholic thought concerning Israel. This engagement was part of the theological renewal defined by the nouvelle théologie, as inaugurated by Henri de Lubac, who proposed a return to the sources (ressourcement) of Christian tradition, especially to the church fathers, in order to overcome the

44 Originally from Hungary, Joseph Stiassny (1920-2007) lost his family to the Nazi extermination. After study in Paris and joining the Order of the Fathers of Sion, he was sent to Jerusalem in 1947.

45 André (later Bruno) Hussar (1911-96) was born in Alexandria, Egypt, to a Hungarian father and French mother, both of them Jews. He moved to France during his studies. In Paris, he converted to Christianity and entered the Dominicans, which, in 1953, sent him to Israel with the task of opening a center for Jewish studies.

46 Charles-Marie-Joseph-Henri de Provenchères (1904-84) was appointed archbishop of Aix-Arles-Embrun at the end of 1945, remaining in this post until 1978. Attentive to Jewish-Christian dialogue, he participated in the Second Vatican Council and also contributed to the debate on the Nostra Aetate declaration. 
neoscholastic attitude that informed the majority of scholarly research of the period. The return to original Christian studies also involved the study of Judeo-Christianity, which indeed became one of the principal objects of interest of the Jesuit theologian Jean Daniélou, editor of the journal Études and a friend of de Lubac. This reflection was not confined to theological speculation and the movement for liturgical reform but extended throughout the contemporary landscape in its demand for a rediscovery of the distant Jewish roots of Christianity.

The 1950s was an initial laboratory for these reflections. The Jewish world picked up on the fact that some events were underway; within the State of Israel too, representatives of the government and of Jewish organizations were following the emerging debate attentively, especially in France. In 1951, Imil Najjar, president of the Egyptian Zionist Federation and advisor to the Egyptian ambassador in Paris, met with some Catholic French figures, including Daniélou and Démann, at a conference dedicated to the "Signification et réalité d'Israël". ${ }^{47}$ In a report to the Israeli ambassador in Paris, Maurice Fisher, Najar remarked on the interest with which his words were received, and Fisher himself underscored this open-mindedness, viewing it as an interesting snapshot of how French Catholics were so different from the prejudicially closed-minded "clan Tardini". 48

In 1953, Yohanan Lavi, a member of the information department of the World Zionist Organization and of the Jewish Agency, also met in Paris with some of the principal intellectuals and philosophers of French Catholicism - including Daniélou once again, as well as Gabriel Marcel (another Jewish convert), François Mauriac and Démann - to gain a better understanding of the developing attitude toward Israel. He also made a stop in Switzerland, where Journet awaited him. As a result of these conversations, Lavi made the connection between the theological and philosophical reflections laid out to him, on the one hand, and the question of the relationship of Christianity to Israel, on the other, including its political manifestation as realized after 1948. For Lavi, the "retour aux racines" was at the center of these reflections: "at the roots, one finds us, one finds us again, us, Israel". 49

The religious orders that were most conspicuous in the context of this debate in France were those that historically had a presence in the

47 ISA, HZ/12/170, Najar to Fisher, "Rencontre avec des catholiques," copy, Paris, February 11, 1951 .

48 ISA, ibid., Fisher to Avner, confidential, Paris, February 12, 1951.

49 ISA, ibid., Yohanan Lavi, "Notes complémentaires à propos de contacts dans les sphères d'intellectuels chrétiens (mai/juin 1953)," translation from French. 
Jewish world, especially the clergy of Notre-Dame de Sion, along with the Assumptionists and Dominicans. Therefore, it is not surprising to find these congregations among the orders to whom the founder members of the ASJ belonged: Stiassny, Héné and Hussar. These three clergymen were united by their Jewish origins and their conversion to Catholicism, followed by the decision to take holy orders. They had studied in Paris and had come into contact with the thought of Maritain, Isaac, Démann and Daniélou. ${ }^{50}$ The tragedy of the Second World War and the Axis occupation of France had given the three priests firsthand experience of antisemitic persecution: Stiassny lost his family to the concentration camps, while Hussar was forced to flee Paris. The Shoah left an incalculably deep mark on their paths to conversion and formation as Christians; they came to interpret the antisemitic extermination, along with the founding of the State of Israel in 1948, as watershed events not only in popular Jewish history, but also in the historical evolution of relations between the Catholic Church and the Jews. ${ }^{51}$ Animated by a desire to acquaint themselves with the new reality of Israel and its composite and complex society, they travelled to the new state after 1948.

Once in Israel, the three religious rapidly immersed themselves in different environments from which Roman Catholic priests had kept their distance. They visited several kibbutzim; they studied Hebrew at Israeli ulpanim; they

50 On relations between Jews and Christians in France in the nineteenth and twentieth centuries, see Paule Berger Marx, Les relations entre les juifs et les catholiques dans la France de l'après-guerre, 1945-1965 (Paris: Cerf, 2009), and Pierre Pierrard, Juifs et catholiques français: D'Edouard Drumont à Jacob Kaplan, 1886-1994 (Paris: Cerf, 1997).

51 See Claire Maligot, "Cesser d'être étranger? Les stratégies de reconnaissance identitaire de la communauté catholique hébréophone en Israël (1948-1967)," Siècles 44 (2018), http:// journals.openedition.org/siecles/3311; Danielle Delmaire and Olivier Rota, "L'CEuvre Saint-Jacques: un nouveau modèle missionnaire en Israël dans les années 1950?" in $L a$ mission catholique aux juifs: Émergence, renouvellement et critique du XIXe sièle à nos jours, ed. Danielle Delmaire, Marie-Hélène Robert and Olivier Rota (Paris: Parole et Silence, 2016); Maria Chiara Rioli, "Chiedere perdono: Un appello da Gerusalemme," in Un mestiere paziente: Gli allievi pisani per Daniele Menozzi, ed. Andrea Mariuzzo, Elena Mazzini, Francesco Mores and Ilaria Pavan (Pisa: ETS, 2017); Rioli, "L'Opera San Giacomo: Una Chiesa ebraica nello stato d'Israele," Materia Giudaica 19, nos. 1-2 (2014); and Delmaire, "La communauté catholique d'expression hébraïque en Isräl. Shoah, judaïsme et christianisme," Revue d'histoire de la Shoah, no. 192 (2010). On the French component of the membership, see Martine Sevegrand, Israël vu par les catholiques français (19451994) (Paris: Karthala, 2014), 75-96. On converts during the Shoah, see Frédéric Gugelot, "Conversions du judaïsme au christianisme en temps de persécution, 1940-1950," in Becker, Juifs et chrétiens. For the preceding period, see Philippe Chenaux, "Du judaïsme au catholicisme: Réseaux de conversion dans l'entre-deux-guerres," in La conversion aux $X I X^{e}$ et $X X^{e}$ siècles, ed. Nadine-Josette Chaline and Jean-Dominique Durand (Arras: Artois Presses Université, 1996). 
started to pray in Hebrew; ${ }^{52}$ they met with political and diplomatic representatives of the new state. The Assumptionist Héné obtained permission to celebrate Mass at a kibbutz he frequented together with his Hebrew class. In their first years of activity in Israel, these priests sought contact with known converted or converting Jews in Jerusalem or in kibbutzim. This was a mostly hidden form of pastoral care, limited to direct and personal contacts, without any formal organization. Hussar had spent the initial portion of his stay in Israel as a chaplain with the De La Salle Christian Brothers in Jaffa, where came into contact with some Jewish converts and so came to know their stories and their difficulties. One of the main problem areas was ensuring that they could celebrate Mass: to attend the parish Eucharist would be to expose themselves to the eyes of Palestinian Christians and Israeli Jews. So, Hussar tried to find a way to officiate at a private Mass. This situation clearly reveals the network Hussar was in the process of weaving. He had developed a friendship with an employee of the US embassy, and he began to meet with the converted Jews and celebrate the Eucharist at this man's house in Ramat Gan, close to Tel Aviv.

Meanwhile, Sr. Magdeleine Hutin, inspired by the spirituality and example of Charles de Foucauld, founded a fraternity of the Little Sisters of Jesus in 1939. Ten years later, Magdeleine, together with other two sisters (one of whom was Myriam Kleinberger), came to Israel, a place of special importance for the community. Indeed, de Foucauld had spent three years in Nazareth (including a few months in Jerusalem), which he later considered crucial for his spiritual journey. Réné Voillaume, the founder of the Little Brothers of Jesus, accompanied the Little Sisters on this first trip. In Israel, this embryonic community of nuns and brothers soon came into contact with some converted Jews. Then, in 1953, the Little Brother of Jesus Jean Leroy (later Yohanan Elihai) arrived from France. His first months were dedicated to studying Hebrew and working in kibbutzim (especially Tse'elim and Sde Eliyahu). During this time, he created strong connections with the protagonists of the ASJ. Leroy and Hussar met in Jaffa and began to imagine how they might create a community (fig. 5.1).

Beginning in 1953, this network of contacts held regular private meetings in Jerusalem with the authorization and support of the new apostolic delegate, Silvio Oddi (1953-57), and Tisserant. ${ }^{53}$ At the end of 1953, Leo Rudloff

$5^{2}$ See the AOSJ, 1945-1959, "Sefer tfilot (kolel nosah se'udat ha-Adon)" [Prayer book, including a copy of the Mass], published in 1948 in Jerusalem at the St. Pierre Institute.

53 "During these first weeks of my Palestinian stay I took care to make contact with that group of priests - whom Your Most Reverend Eminence knows very well - who are occupied with, or rather preoccupied with, doing something in favor of the numerous Catholics, converted or not, currently living in Israel. I also attended two of their meetings, and I had 


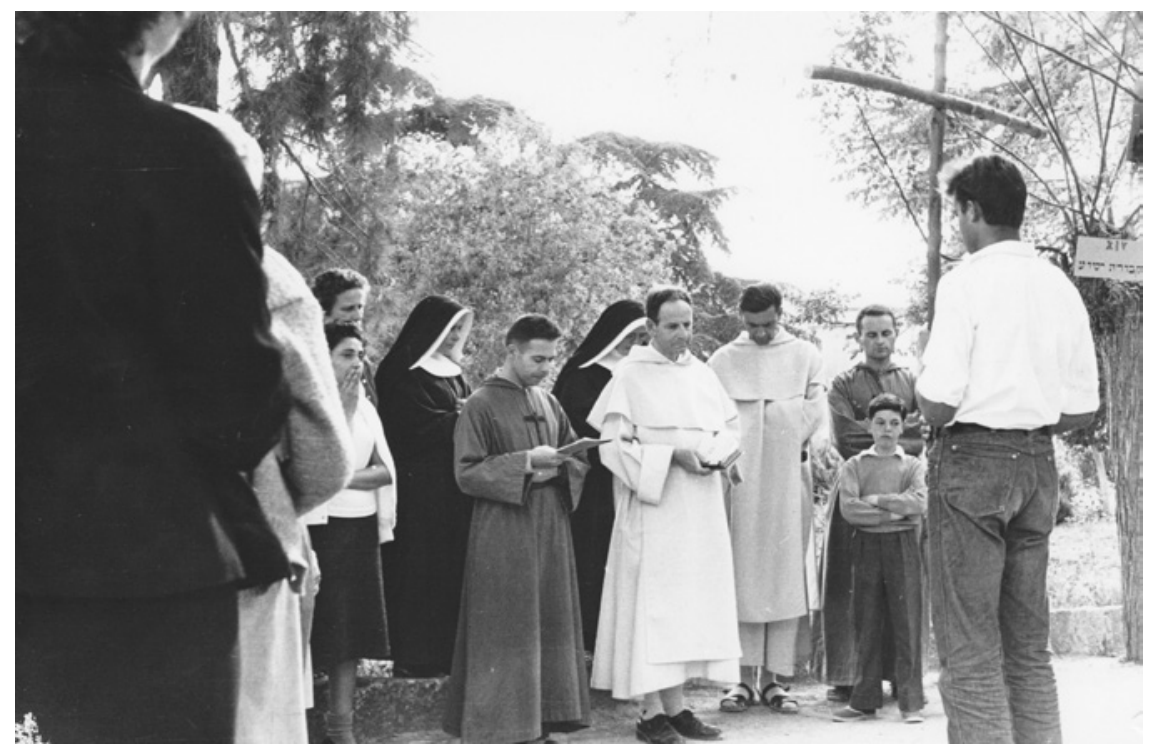

FIGURE 5.1 Jean Leroy and Bruno Hussar, Procession of the Cross at 'Ayn Karim, Good Friday, 1957 ASNDS/AEBAF

became the president of this monthly meeting. ${ }^{54}$ In the autumn of 1954, news of these gatherings also reached the patriarchate. In the spring of the same year, Vergani, who was already acquainted with Hussar and had met with him, discussed the situation of converted Jews with Tisserant and the Oriental Congregation assessor Gabriel Coussa during a trip to Rome. ${ }^{55}$ In the course of this meeting, the secretary of the Oriental Congregation lamented Gori's lack of interest in this subject, adding that Démann had reported to the French cardinal the patriarch's surprise at the celebration of the confirmation of a group of converted Jews. Vergani defended Gori's behavior, explaining that the diocese had adopted an attitude of "prudence and seriousness", which, according to the vicar for Galilee, was greatly appreciated by various Israeli

the impression that these are excellent elements." Aco, Latini, Palestina e Transgiordania: Patriarcato di Gerusalemme, 855/49, 2, doc. 164, Oddi to Tisserant, Jerusalem, February 2, 1954, translation from Italian.

54 See ACO, ibid., doc. 162, Stiassny and Héné to Tisserant, Jerusalem, November 9, 1953.

55 APDF, BS, Hussar, V 840, 14, confidential report from Hussar to the Dominican provincial Albert-Marie Avril, Paris, September 11, 1954. He wrote that his relations with the patriarchal authority were "excellent" and that he kept the vicar informed of his ministry "in broad outlines". 
representatives, including Colbi. ${ }^{56}$ This did not mean abandoning the apostolate to Israel; to prove this, the vicar of Galilee spoke of the "conversion of 20-25 persons per month (Jews or Hebraized Christians)". Gori later wrote to Vergani that, as regards the Jews, "we desire their conversion and cooperate as zealously as possible". ${ }^{57}$ Toward the end of 1954, the patriarch asked Vergani to participate in meetings between priests and catechumens being held in Jerusalem and to report back to him with his observations. ${ }^{58}$ In a certain sense, the patriarchate was obliged to get involved in the affairs of the ASJ, given the active interest of Tisserant as well as the apostolic delegate and some religious orders in Jerusalem. However, most importantly, the meeting in which Vergani participated constituted the founding meeting of the AsJ. The period of private meetings was over; the group now became an association of the patriarchate, albeit little known and almost hidden within the diocese.

\section{$2.2 \quad$ The Birth of the Association of Saint James}

The meeting at which the ASJ was founded took place on November 12, 1954.59 The discussion started with an analysis of the situation of Catholics of Jewish origin in Israel. To respond to the needs of a "group of Judeo-Christians in Israel", the attendants discussed the plan to open up in Jerusalem, Haifa, and Jaffa "the Hом Es, ${ }^{60}$ intended to receive persons who desire to work and live (orph[ans] and widows of Jewish husbands, women of advanced age, homeless

56 ACo, Latini, Palestina e Transgiordania: Patriarcato di Gerusalemme, 858/49, 2, doc. 143, Vergani to Coussa, Strambino (Turin), June 17, 1954, translation from Italian.

57 APLJ, LB-AG, Vicariat Galilée, 1946-1956, Gori to Vergani, Jerusalem, July 7, 1954, translation from Italian.

$5^{8}$ Addressing Gori, Vergani appended a letter in which he wrote: "Truly, I felt that there had to be something plotting, but I could never be quite sure; today, I know it: during my visit to Rome, Cardinal Tisserant and the Assessor insisted to me that Y[our] B[eatitude] did nothing for the conversion of the Jews. Now I have come to know that in Jerusalem, for more than a year, His Excellence the Apostolic Delegate has met at the Biblical Institute with several clergy who applied for an apostolate to the Jews and, naturally, the minutes were sent to the Congregation; since then neither the Patriarch nor the Vicar figured, here is the accusation of lack of interest. I tell you in all conscience that I never knew anything of these meetings." APLJ, Opera S. Giacomo, 1954-1959, Vergani to Gori, Haifa, December 12, 1954, translation from Italian.

59 APLJ, ibid., report of the founding meeting of the ASJ: "Opera S. Giacomo ap. Seduta I," typescript text with autograph signature of Vergani, Jerusalem, November 12, 1954, translation from Italian. The minutes of the meeting were also sent to the apostolic delegate to be delivered to Tisserant. See ACo, Latini, Palestina e Transgiordania: Patriarcato di Gerusalemme, 855/49, 2, doc. 178, Oddi to Tisserant, Jerusalem, December 22, 1954.

6o APLJ, Opera S. Giacomo, 1954-1959, report of the founding meeting of the ASJ, capitalized in original. The Italian word "focolari" is the translation of the French word "foyer" that would be used in the association's documents. 
youth, families who have lost their livelihoods due to their conversion until they can be accommodated)". Outside the State of Israel, the plan was to establish "MIXED CIRCLES OF FRIENDSHIP, that is, of Judeo-Christians, wherein an atmosphere of understanding relating to matters Israeli could be cultivated, where the simple oppositions could be dispensed with; where funds could be raised to help the Judeo-Catholic community in Israel; where cultural, social, educational, and aid initiatives for the same can be supported."61 In the minds of the founders, the ideas behind these circles should be propagated by means of a report "suitable to inform and rectify public opinion on Israel, both to the outside world concerning the Judeo-Catholic community in Israel, and in Israel itself in an atmosphere of mutual understanding". ${ }^{62}$

With these objectives in mind, some fundamental questions remained open. In first place was the problem (pointed out by Stiassny) of reconciling diverse goals and activities: raising funds for the converted Jews in Israel, supporting them from an economic and material standpoint, by way of addressing the social isolation to which they were subjected; and building a bridge between the church and Israel in order to increase "respect and understanding". ${ }^{63}$ On this last point, the issue was that it would be difficult to build a relationship of mutual trust between Christians and Jews if Jewish society perceived the ASJ as an entity that financed converts to Christianity.

There were no immediate answers to their questions. Several members of the founding committee requested that the nascent association should present and develop a profile of itself as a group of laity rather than clergy; they thought that in this way they would be able to avoid too close an identification between the Latin Church and ASJ members. In any case, the emphasis on the association's lay character - which would continue as a central element in its history - would accompany the questions around the connection between the ASJ and the local church.

Furthermore, with the foundation of the association, another fundamental set of issues emerged as it developed: the question of the foyers, the homes for converted Jews. Generally founded by priests of the nascent association, these

61 Ibid., capitalized in original.

62 The intention was to circulate this document in Israel to affirm that "the converts are not a fifth column for nothing; they are loyal citizens of Israel ... the Catholic Church has never made use of material means to attract Jews", and its work should not be confused with the proselytizing action undertaken by Protestant missionaries and agencies. APLJ, Opera S. Giacomo, 1954-1959, minutes of the foundational meeting for the ASJ: "Opera S. Giacomo ap. Seduta I," typescript text with autograph signature of Vergani, Jerusalem, November 12, 1954.

63 Ibid. 
were conceived in response to the sense of isolation experienced by converts. As such, they were private spaces where the converts could meet, hold discussions and celebrate the Eucharist.

The inaugural meeting of the society concluded with the nomination of a provisional committee, which would meet once a month, consisting of Vergani, Stiassny, Héné and Joshua Bergman, leaving open the possibility of participation by Hussar and the Carmelite Elias Friedman. The name of the association was also approved; Bergman requested that a saint be chosen as the group's protector, and Vergani proposed it be dedicated to Saint James the Apostle, the first bishop of Jerusalem in the biblical tradition. Thus, he intended to further highlight the connection between the just-formed group of converted Jews and the Judeo-Christian community of early Christianity. In fact, references to the ASJ as modern Judeo-Christians of sorts also permeated the founding statutes of the association. ${ }^{64}$

\subsection{The Complex Drafting of the Statutes}

Vergani's inclusion in the founding group of the ASJ was intended to guarantee a presence - and, in a sense, also the control - of the Latin Patriarchate in such a delicate pastoral care environment as the Jewish world. The other committee members were aware that the freedom of action and lay character with which they intended to invest the association would be limited by the guidance exerted by the patriarchate. In any case, the desire not to compromise relations with the local church, which were already complicated by the hostility toward Jews of the Arab and European clergy, led them to exercise special caution and to be especially open to requests from the patriarchate.

On February 11, 1955, Gori approved the ASJ ad experimentum, constituted, as the patriarchal decree specified, "to organize and coordinate the apostolate's diverse activities and to provide assistance in Israel to Christian families and families who have converted from Judaism". ${ }^{65}$ The bishop provisionally authorized the association for one year, at which point its future would be decided upon. Besides the institution of a central committee, local groups were created shortly thereafter in the cities that received the greatest number of Christians of Jewish origin or converted Jews.

What exactly was the association proposing? What were the goals and motivations of its founders? The association's central committee responded to these

64 The definition of the group as an "incipient Judeo-Christian community in Israel" recurs at least eight times in the text of the minutes.

65 APLJ, Opera S. Giacomo, 1954-1959, decree no. 4/55, typescript document with Gori's autograph signature, Jerusalem, February 11, 1955, translation from Italian. 
questions by elaborating its statutes in a document that inspired and guided its subsequent actions. Creating the statutes required several months of work; various versions were discussed and compared, and it was produced with meticulous attention to detail. ${ }^{66}$ Throughout 1955 , the association's members were absorbed with the task of ironing out the various topics under discussion.

The first part of the statutes dealt with the aims and activities of the ASJ, which were to "preserve and uphold Christianity in Israel, particularly the Catholics converted from Judaism". However, it "did not intend to replace any existing associations, but wished to respond to the needs resulting from the demographic changes that had taken place in the country". ${ }^{67}$ In the second version of the statutes, drafted in September 1955, this last phrase is worded differently, affirming that the association "is to be considered among existing associations that focus on Arab Christianity". ${ }^{68}$ This formulation clarifies more precisely that the ASJ did not intend to address the Arab Christian world, but would not oppose it either. This allusion to the Arab component of the Catholic Church does not appear in the next draft of the statutes, probably out of fear that it could provoke more tension than dialogue within the Jerusalem diocese, which would generate opposition to the association.

After laying out the goals, the statutes moved on to describe the association's activities. The wording of this portion was one of the most heavily discussed, beginning with the first draft in June 1955. It explained that the association had a dual purpose, spiritual and social. In the first category, the text lays out a series of direct intentions aimed especially at defending the church from accusations from on the Israeli side. It also refers to preaching and the promotion of popular missions in the country's various languages. The keen attention paid to the "study of the problem of Israel", along with the diffusion of a "Judeo-Christian culture" and spirituality, is significant. ${ }^{69}$

The versions that followed proved to be highly diverse; they no longer emphasized the necessity for public intervention in defense of converted Jews on the part of the association and made no further mention to the problem of Israel. In its place was the mystery of Israel, a much weightier formulation that took account of the Maritain perspectives. ${ }^{70}$ The association, then, aspired

66 See APNDs, P. Stiassny, confidential report titled "Compte-rendu de l'CEuvre, novembre 1954-mai 1956," drafted by Vergani and Héné, Haifa, May 14, 1956.

67 APLJ, Opera S. Giacomo, 1954-1959, "Statuts," translation from French. The AOsJ also contains a handwritten copy of the statutes in Hebrew ("Mif'al Yacaḳov ha-Tsadik Taḳanon").

68 APNDs, P. Stiassny, "Projet de statuts," September 11, 1955, translation from French.

69 APNDS, ibid., "Projet de statuts," Haifa, June 19, 1955, translation from French.

70 "The association will develop a solid Christian spirit among its members. Efforts will be made to acquire intelligence concerning the mystery of Israel; training in the Bible will 
to give rise to a spiritual consciousness capable of linking the Christian and Jewish traditions. The founding figures of the nascent association were aware that they were embarking on an extremely delicate and complex experience while, at the same time, affirming their intention not to propose a rule of communal life and prayer that was extraneous to or different from the teachings of the church. In any case, emphasis on the struggle against antisemitism "in all its guises", and on the activity that the statutes anticipated, showed that in fact they were pursuing paths and goals up to that moment unheard of by the church of Jerusalem and, for the time being, abandoned by the Vatican, as is shown by the dissolution of the Amici Israel. ${ }^{11}$

When it came to social activities, therefore, the ASJ requested that the Israeli state guarantee the freedom of religion and of education. Proselytism by converts did not appear among the association's objectives; to the contrary, the convert had the responsibility to demonstrate, through his testimony of faith and way of life, the possibility of conjoining Christianity and Judaism, but not to renounce his proper national Israeli affiliation. ${ }^{72}$

The decision to remove the name of Alphonse Ratisbonne from the list of the association's patrons further clarified, on the one hand, the fears that any part of the statutes could nurture the polemic against Catholic proselytism in Israel. On the other, it demonstrated the growing will on the part of the association to abandon the conversionist activities historically pursued by the church in the name of a new encounter with Israel and the Jewish world.

The correction regarding Ratisbonne brought the drafting of the statutes to an end (fig. 5.2). These had in fact already been presented to Gori in February 1956, at the end of the AsJ's probationary year. He accepted the statutes and formally approved the association..$^{73}$ On the same day, February 11 ,

be insisted upon, and we will strive to promote a Judeo-Christian culture and accompanying spirituality ... We will do all in our power to dissipate the prejudice whereby a Jew who has embraced the Christian religion has abandoned his people ... Far more, as a Christian issuing from Judaism, he should recognize his special vocation within the Church and among his people and assume the responsibility that follows." APLJ, Opera S. Giacomo 1954-1959, "Statuts."

71 "In its desire to be a link between the Jewish people and Christianity, the association will combat antisemitism in all its guises and make efforts to develop mutual understanding, sympathy, and amicable relations between the Catholic world and Israel." Ibid.

72 The first draft refers explicitly to the "absolute loyalty to the State of Israel and its laws" on the part of the association's members. APNDs, P. Stiassny, "Projet de statuts," l, September 11, 1955 .

73 See APLJ, Opera S. Giacomo, 1954-1959, decree no. 7/56, signed by Gori and Beltritti, Jerusalem, February 11, 1956. 


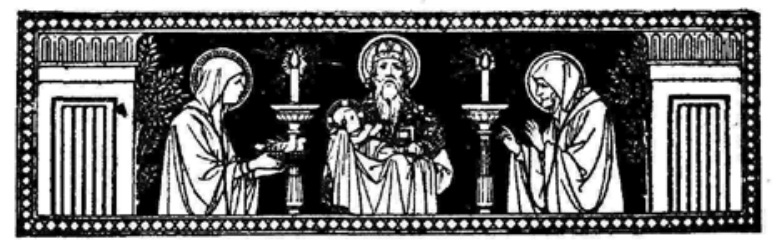

- LUMen ad revelationem gentium et gloriam plebis tug isRaet,

\section{OEUVRE SAINT JACQULS L'APOTRE}

\section{STATUTS}

FIGURE 5.2 Statutes of the Association of Saint James, cover page, 1956

AOsJ

Vergani was nominated president of the association. The apostolic delegate, Oddi, also communicated to the patriarch the pleasure of Pius XII at the establishment of the association. With papal approval, a new phase of work began for "this little kernel that has scarcely seen the light". ${ }^{4}$

3.1 The Communities and the Foyers

One of the most important priorities identified in the first year of the AsJ's existence was that of opening up spaces - foyers - to receive, in a more-or-less stable fashion, the nascent communities of Jewish converts to Catholicism. Meeting places had to be found to hold prayer meetings and Bible study sessions but also for sociopolitical purposes. Responding to this urgent need would touch on various issues, especially the fact that most of the Catholics of Jewish origin in Israel "live in isolation, in fear, they feel themselves separate

74 APLJ, ibid., Vergani to Gori, Jerusalem, May 8, 1956, translation from Italian. 
from the community of their Jewish brothers while not being fully integrated into that of the Church". 75

It was not just the need for a private space in which to freely express their faith that drove the search for new environments. The desire for a shared space for catechumens and converts also responded to another need inherent in the process of identity formation that the young community of Catholics of Jewish origin was undergoing. The sharing of spaces and moments of encounter, and of meals like the Eucharistic celebration, reflected this image of the Judeo-Christian protocommunity toward which the converts in the State of Israel were inspired. Finally, for the converts to be able to identify with a specific space in which they would eventually reside would follow a longstanding historical tradition; suffice it to mention the houses of the catechumens, established for converts which received (and confined) neophytes, particularly Jewish ones in Italy and elsewhere from the mid-sixteenth to the beginning of the twentieth centuries, so that they could receive instruction in Catholicism. The foyers of the ASJ, although they came into being with profoundly different goals and methods, thus constituted a space where the converts could develop in the faith and meet one another.

The first foyer was established in Ramat Gan, near Tel Aviv and Jaffa, under Hussar's pastoral care. ${ }^{76}$ After a suitable apartment was found, its rooms were allocated for use as an oratory, a library, a meeting room for about sixty persons, a laboratory and an office for the chaplain's secretary. The foyer's premises were blessed on February 14, 1956, and it was dedicated to Saint Simeon, a biblical figure who also featured in the association's statutes. ${ }^{77}$ From its beginnings, the foyer hosted various types of activity. Over the course of 1956 , Mass was

75 AOSJ, 1945-1959, brochure on the ASJ, September 15, 1956.

76 Oddi had required the custody to let two rooms to Hussar in St Peter's monastery in Jaffa, but the Franciscans refused. Oddi reiterated a request for aid to the custody to cover the rent of the foyer, a proposal that the friars accepted. See AAV, ADAGP, 20, 81, 5 , fol. 267 , Teofilo Bellorini, Custodial president, to Oddi, Jerusalem, August 18, 1955 .

77 The statutes open with this biblical verse: "A light to lighten the gentiles and to be the glory of thy people Israel." APLJ, Opera S. Giacomo, 1954-1959, "Statuts." This is a significant quotation from the "Nunc dimittis", or Canticle of Simeon (Luke 2:29-32). Like the ancient figure in the Gospel story, the members of the association, too, were Jews who had recognized the divinity of Jesus. At the same time, it is interesting to note that in this verse it was not the Jews who would be illuminated by divine grace, but the gentiles. In the "Nunc dimittis," as in the association's statutes, then, the Jews were not represented in the image of a people blind to the Christian revelation, a symbolism that had dominated for centuries, nurturing Catholic anti-Jewish prejudice. To the contrary, the verse refers to Jesus's Jewishness and to the election of Israel that the Christians, too, were required to acknowledge. 
celebrated there every Sunday evening with about twenty people in attendance. The second reading and the Gospel were read in Hebrew, and the sermon was delivered in Hebrew and French. There were also weekly meetings for spiritual instruction. Concerts of sacred classical music and French lessons were also organized, and a small library was set up.

On the cultural level, particular attention was devoted to organizing a series of conferences. Insights were presented relating to church history as well as to events in Zionist history. There was also a cycle of lessons on biblical themes dedicated to the "fates of Israel", a phrasing that echoed the volume published in 1945 by Charles Journet. ${ }^{78}$ These conferences were offered in English and were attended by around twenty members of the US, Canadian, British and Australian diplomatic corps, which formed a group called the Friends of Saint James. ${ }^{79}$ Here, the political implications of the association's activities were revealed for the first time; these would be reinforced over the years and would address themes linked not only to church history and relations between Christians and Jews but also to analyzing the fundamental features of Zionism. In this way, the nascent association proposed to open up a deeper reflection - limited to just a few persons for the time being - concerning the historical significance of the establishment of the State of Israel for the church, overcoming the hostility or indifference that had characterized the Catholic hierarchy and the majority of those who had expressed a view on these matters. This particular sensibility of the members of the association was born of internal conflict, but also resulted from external suggestions, especially those of some rabbis and numerous pilgrims who had come to Israel and, when visiting the foyer, had questioned its members on the possibility of overcoming the separation of the association from the Catholic Church and from Israeli society.

Building upon the experience of Tel Aviv-Jaffa, the association looked into the possibility of opening a foyer in Haifa led by the Carmelite Elias Friedman. A member of the central committee of the AsJ, he was actively engaged in preaching on Jewish-Christian relations to diverse religious communities. In some of these religious communities, the practice of praying in Hebrew had become commonplace.

As the association's various centers organized and grew, certain tendencies emerged more and more clearly. In Tel Aviv, the primary motivation was to create and consolidate the "fraternal life" of a group attuned to the spiritual and

78 Journet, Destinées d'Israël.

79 AOSJ, 1945-1959, brochure on the ASJ, September 15, $195^{6}$. 
material needs of its own members. ${ }^{80}$ Meanwhile, in Haifa, the association's work focused primarily on religious congregations already existing in Galilee, organizing meetings and lessons that would stimulate new reflections on the relations between Christians and Jews. Finally, in Jerusalem, the political and cultural aspects were to the fore, albeit in an extremely prudent and cautious manner so as to avoid the accusation of pro-Israeli attachments on the part of the local church or polemics on the Jewish front. This explains the private networking that was done with some representatives of the Israeli state. In 1956, AsJ representatives, led by the Bible scholar and Dominican Raymond-Jacques Tournay, visited Israeli President Yitshak Ben-Zvi, presenting him with a copy of the Bible edited by the École biblique et archéologique française. Some of the association's priests who lived in the Holy City also initiated a collaboration with a group of pilgrims - both Jewish and Christian - with the aim of presenting the small and hidden reality of Saint James to visitors as well. Hussar then met with various religious communities in Israel for spiritual retreats and conferences. Finally, the Assumptionist Jean-Roger Héné was chosen to celebrate Mass in some kibbutzim in the Negev desert in the environs of Beersheba. In fact, it was the interest in the experience of collectivism in Israel that had attracted several members of the association and induced them to develop an unprecedented experience in the life of the young community.

\subsection{A Catholic Kibbutz for Converted Jews}

Reflection on the forms of communal life within the ASJ was not limited to establishing the foyers; it drove them to consider opening a Christian kibbutz for families of converts or of Christians of Jewish origin. The proposal boasted some especially original features, particularly given the interest the Catholic world had developed about the Jewish agricultural cooperative model that had arisen in Palestine and developed further after the establishment of the State of Israel. In the course of his pastoral incumbency, Barlassina had identified the Jewish collectivist movement as the clearest token of the danger of the spread of communism within the diocese. In the eyes of many in the Latin Church of Jerusalem, kibbutzim were thus synonymous with atheist collectivism and materialism. ${ }^{81}$ In the last months of Barlassina's life, rumors spread within the patriarchate of an imminent opening by a Protestant society of a kibbutz for Jews who had converted to Christianity. The locus of the intended reform

80 APLJ, VB-GB, Dominicains, 1874-1980, Hussar to Gori, Jaffa, August 1, 1955.

81 For a historical appraisal of the Jewish collectivist movement, see Henry Near, The Kibbutz Movement: A History, 2 vols. (Oxford: Oxford University Press, 1992-97). 
congregation would be the property of the Benedictines at Abu Ghush. In any case, the initiative was not followed through.

At the end of the 1940s, the proposal to establish a Catholic kibbutz for converted Jews resurfaced. This time, the Secretariat of State intervened, despite Testa's reservations: ${ }^{82}$ informing the Vatican that "the Jews, with the intention to take over the Catholic properties in Palestine, were making attractive propositions to the religious congregations to sell their land", the secretary of the Congregation for Extraordinary Ecclesiastical Affairs, Tardini, relaunched the idea of giving work in these lands "to the converted Jews, whose situation is so precarious". ${ }^{33}$ Vergani shared the idea of founding agricultural colonies, particularly in the area of Rafat. According to the Latin vicar for Galilee, political reasons impeded these kinds of foundation for Jews already in Israel, while it was better to focus on "young European people coming to Israel with the religious nationalist ideal of the PIONEERS, that is REAL ZIONIST CHRISTIANS". 84

Gori was unenthused at the prospect of a Catholic-collectivist enterprise and had serious reservations about the project. However, it found new life with the establishment of the ASJ, although in other forms. Some priests and laity among the ASJ founders did not share the reservations and fears of the vast majority of clergy in the Jerusalem Latin diocese. Their perception of the complex reality of the new state had passed through the experience of the kibbutz - many of them had spent significant time studying Hebrew and doing agricultural work in them - and they remained profoundly fascinated by it. The result was an idealized vision of the Jewish collectivist agricultural movement according to which the kibbutz expressed an egalitarian model of the division of goods, tolerance between inhabitants and respect for natural resources. Hussar, Héné and also some lay members like Joshua Bergman, identified the Israeli cooperative agricultural life with the Gospel ideal of sharing resources and living communally. Furthermore, some members of the association - especially the members of the Little Brothers of Jesus - were influenced by their experience of priest workers in France; ${ }^{85}$ thus, the reality of the kibbutz seemed to them to

82 According to the apostolic delegate, the idea, "beautiful in itself", was impossible to realize due to the "fanaticism of Israel". ACO, Latini, Palestina e Transgiordania: Patriarcato di Gerusalemme, 855/49, 2, fol. 121, Testa to Tisserant, Jerusalem, November 17, 1949, translation from Italian.

83 ACO, ibid., $858 / 49$, 2, fol. 92, Tardini to Valeri, Vatican, April 21, 1950, translation from Italian.

84 ACO, ibid., fols. 101-4, Vergani to Tisserant, Nazareth, June 30, 1950, translation from Italian.

85 The phenomenon of worker priests (prêtres ouvriers) had its beginnings during the Second World War, when some priests were sent to work in the industries in France under Nazi occupation. This enabled them to acquire first-hand experience of the condition of 
correspond to the various experiences from within the Christian environment as well. In those years, interest in the kibbutzim was also growing in Catholic contexts outside Israel. In his meetings with intellectuals in France and elsewhere, Yohanan Lavi had noticed a marked sensitivity toward certain aspects that were defined as "pre-Christian" or even thoroughly "Christian" in the lives of the Jewish communities in Israel. ${ }^{86}$

The next step was to contemplate the possibility of creating a kibbutz for Jews who had converted to Christianity. Even before the priests of the ASJ suggested it, Latin priests in Israel and Vergani himself had explored the feasibility of the idea. The priests discussed this project during a meeting in autumn 1950. ${ }^{87}$ The choice of Dayr Rafat as the location of a kibbutz to be run by the families of converted Jews was also supported by Georges Sfeir, a Lebanese medical doctor who lived in Jaffa and was interested in renting part of the patriarchate's property in order to create a "Catholic collective". ${ }^{88}$ Sfeir's proposal was presented as a conglomeration that would combine collectivism and the retention of private property. The patriarch himself seems to have been very diffident about this "kibbutz sui generis", dubbing it "a chimerical project". 89

the working class, which was generally unknown at that time in the Catholic Church. The publication of the book France, pays de mission? (Paris: Cerf, 1943) by two French priests (Henri Godin and Yvan Daniel) and the establishment, a year later, of the Mission de Paris for the working classes and their families by the archbishop of Paris, Cardinal Suhard, represented the beginning of a historic phase in which priests were sent to work in factories, divested of their religious habits and quickly became engaged in trade unionist struggles. This social and political involvement was immediately viewed with suspicion by Rome, fearful of procommunist sentiments within the clergy. Pius XII decreed an end to the experiment in 1954. Despite the papal prohibition, the worker priest movement did not come to an end. It was rehabilitated in the 1960s by Paul vi after some priests who had been involved in the experience, among them Paul Gauthier, who was well acquainted with Israel and the members of the AsJ, participated in the Second Vatican Council. For a historical treatment of the phenomenon, see Émile Poulat, Les prêtres-ouvriers: Naissance et fin (Paris: Cerf, 1999).

86 See ISA, $\mathrm{Hz} / 12 / 17 \mathrm{O}$, Lavi, "Notes complémentaires à propos de contacts dans les spheres d'intellectuels chretiens (mai/juin 1953)," translation from French.

87 APLJ, LB-AG, Vicariat Galilée, 1946-1956, "Riunione dei parroci latini in Israele," 1st session, typescript, Haifa, November 8, 195 o.

88 APLJ, LB-MS, Deir Rafat 1941-2007, "Projet," unsigned typescript document in French, undated (ca. second half 1950). The scarcity of information found in the patriarchal archive related to this figure makes it hard to trace its full outlines. It is probable, however, that it was the same Dr. Georges Sfeir who, a few years later, operated on Hussar in Jaffa and whom he recalls "as a friend". See Bruno Hussar, Quando la nube si alzava: La pace è possibile (Genoa: Marietti, 1996), 49.

89 APLJ, LB-MS, Deir Rafat, 1941-2007, handwritten note by Gori on the Sfeir project, translation from Italian. 
The initiative appears to have been realized to a certain extent, given that three years later, after his trip to the Middle East, Thomas McMahon could refer to a kibbutz created by the patriarchal curate in Rafat, Domenico Veglio, and composed of about 50 converted Jews at that time. The PMP president judged the project one of the most innovative experiments put into action by the patriarchate toward the "Nicodemus Christians", the converted Jews who were otherwise hidden within the Latin church. ${ }^{90}$ In McMahon's analysis, the utility of this experiment was further legitimated by the fact that the "Jew", unlike the "Arab", was intrinsically inclined to collective work and was thus particularly receptive, once converted, to the goals and methods of Catholic social doctrine. ${ }^{91}$

Sources on the experiment begun by Veglio are scarce and lacunose; in any case, it is certain that the opening up of agricultural enterprises run by converted Jews and oriented to the collectivist Jewish model attracted a certain amount of attention from other clergy and represented an ideal cherished by various religious congregations and the AsJ itself. This is demonstrated by the fact that the nuns of Saint Joseph of the Apparition, probably together with Hussar, decided to rent out their holding at Bet Dagon, in the environs of Ramat Gan, to a group of converted Jews, initiating an experiment that lasted only a few months. Oddi, the apostolic delegate, took an interest in this case; he judged that "the failure of this effort should not, however, be discouraging; they can make other attempts both in the agricultural context and in other sectors". ${ }^{92}$ Meanwhile, the patriarch reiterated to Oddi the possibility of an agricultural school at Bayt Jimal, where the Christians of Jewish origin could be employed, but this suggestion does not seem to have been followed through.

Reflection on these subjects would continue within the ASJ. Hussar termed it "the most seductive aspect, because [the rural communities] corresponded most closely to the pure Zionist ideal, and at the same time to the communitarian religious ideal of some young Christians and catechumens". ${ }^{93}$ The laity in the association were particularly active in the realization of a kibbutz for

90 AANY, ACNEWA, "Report on Journey of Msgr. Thomas J. McMahon in Middle East - Oct. 18 through Nov. 12 1953," written by McMahon himself. He expected that this type of project could be extended to be actualized elsewhere in Israel and aired the possibility of opening another kibbutz on Salesian property in Bayt Jimal, not far from Dayr Rafat.

91 "The Arab is an individualist; the Jew is not. Imbuing the Arab with the social encyclicals will be a long, hard road." Ibid.

92 APLJ, LB-AG, Délégué Apostolique, 1943-1955, Oddi to Gori, confidential, Jerusalem, February 15, 1955, translation from Italian.

93 APDF, BS, Hussar, V 840, 14, confidential report from Hussar to Avril, Paris, September 11, 1954, translation from French. 
converted Jews. Even before the foundation of the AsJ, Bergman had made known his desire to open a kibbutz for Jewish Catholics in Israel, an idea in whose service he mobilized friends in Europe and the United States.

Along with Bergman, a couple had also long been interested in establishing a Catholic kibbutz. The wish to open up an environment that would guarantee a Christian education for their children united the couple and other laity in the association who were already living in kibbutzim. ${ }^{94}$ The willingness of the nuns of Notre-Dame de Sion to place a piece of land at 'Ayn Karim at their disposal enabled them to open up a Christian community, founded by a group of lay converted Jews. In January 1957, Héné and a family of converted Jews inaugurated this presence at 'Ayn Karim, which would become one of the association's most important focal points for prayers and meetings (fig. 5.3). ${ }^{95}$ This opened a new phase in the life of the association; after the first years of clandestine meetings and uncertain steps, the ASJ membership grew and initiated a communal life that was unique in the Latin Church of the period.

\section{$3 \cdot 3$}

\section{"The Love of Israel" or "The Return to Christ"? The Identity Formation of the "Jewish Christians"}

One of the fundamental questions faced by the ASJ in its first years of existence was the form the apostolate should take in Israel, both toward those who

94 See APNDS, P. Stiassny, minutes of the meeting of the Committee of the AsJ, 'Ayn Karim, June 14, 1957 .

95 On the eve of the beginning of this new experience, Héné wrote to Tisserant: "We will try to remain faithful to our ideal of Christianity within our people [Israel] and for that we will remain affiliated to the Union of Workers (Histadrut), etc.... We must make our people understand that a Christian can very well be a good citizen and a good patriot." ACO, Latini, Palestina e Transgiordania:Patriarcato di Gerusalemme, 855/49, 3, doc. 318, Tse'elim, January 23, 1957, translation from French. At the end of the 196os, the ideal of community life, animated by Christian principles but also influenced by the experience of the work of the Zionist pioneers, would influence the birth and development of the Arab-Israeli village of Neveh Shalom-Wahat al-Salam (NSWAS), on the outskirts of Latrun, founded by Hussar and a group of laymen, some of whom - like Rina Geftman - came from the experience of the ASJ. The NSWAS project differed from the attempted enterprise at 'Ayn Karim because the goals included not only the realization of a Catholic-oriented kibbutz for converted Jews, but also the creation of a mixed Arab-Jewish village, thus demonstrating the possibility of peaceful cohabitation between the two peoples who were in conflict. In any case, within this "dream," as Hussar termed it, diverse elements came together that characterized first the association's foyers and then the 'Ayn Karim project. For historical insight into the events related to NSWAS, see Maria Chiara Rioli, "A Christian Look at the Israeli-Palestinian Conflict: Bruno Hussar and the Foundation of 'Neve Shalom/Wahat Al-Salam,"' Quest: Issues in Contemporary Jewish History, no. 5 (2013). 


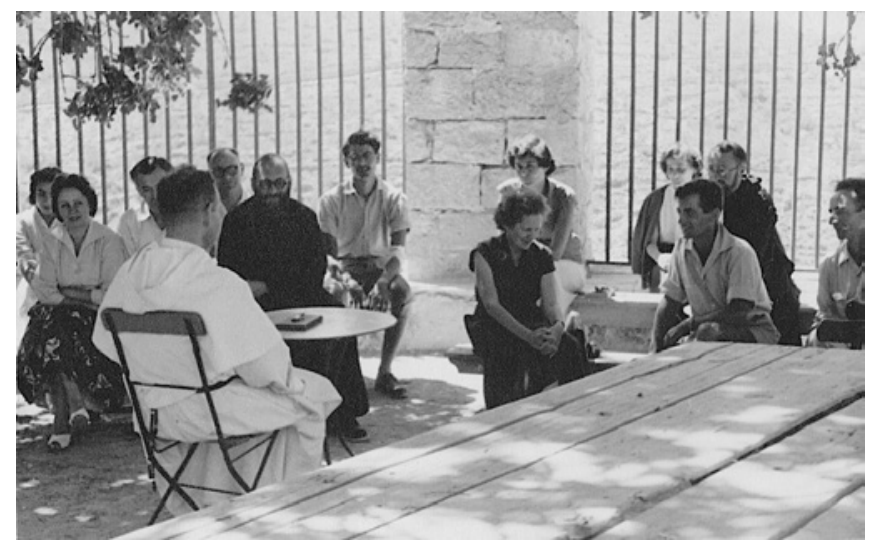

FIGURE 5.3 Association of Saint James meeting at 'Ayn Karim, 1957 ASNDS

approached it to request the sacraments and toward those who, despite their Jewish origins, had belonged to Christian families for generations.

A passage from a discussion on the problem of Israel - the term initially proposed in the drafts of the statutes, as was seen above, and later referred to as the mystery of Israel summarizes the association's new approach. The rejection of expressions like Jewish problem or question, with their historical baggage permeated with anti-Judaism and - from the nineteenth century on antisemitism, and working, on the contrary, toward an approach to the Jewish world that was respectful and not oriented toward conversion, represented one of the ASJ's principal contributions within the greater context of change in the relations between Jews and Christians, and of the Christian perception of the Jewish world that had emerged in the mid-twentieth century.

The association's founder members were aware, to varying degrees, of these transformations in the traditional Catholic attitude toward the catechumens. In a document probably dating from 1956 , ASJ members reflected on the necessity to distinguish between "active" proselytism, in their view absolutely to be avoided in Israel and also not appropriate for the Jews of the diaspora, and "passive" proselytism, identified in the Jews who approached the association to request the sacraments, which was also problematic in the Israeli social context. The association's chosen structure also defined the evangelizing strategy that they would adopt, in a direction aimed at overcoming both forms of proselytism, in order to channel the association toward another type of pastoral care: the "apostolate of presence", of "rapprochement". This was based on "a new encounter between the Jewish people and the Church of God" with the purpose of "improving Judeo-Catholic relations based on areas of 
shared interest: the country of the Holy Land, the Bible, the Revelation".96 As Stiassny stated,

the precondition for the apostolate of presence is sympathy. To be present to someone, to achieve a true spiritual presence, we must love ... as long as there remain in our subconscious traces of antisemitism, of feeling of superiority, we will not arrive, by an effort of love, to identify ourselves with the spiritual (and not political) destinies of Israel.

Echoing Paul, he concluded that "you have to be Greek with the Greeks, Hindu with the Hindus and Jewish with the Jews".97

The fact that conversionist activities were not encouraged is also demonstrated in the content of some letters from Hussar to Patriarch Gori in which the Dominican argued for his choice of focusing on those who had already completed the conversion process, especially by preparing catechumens for baptism. The energies of Hussar, himself a convert, were also directed to the study of Judaism, with the purpose of gaining insight into its origins and those of the members of the Jaffa community. ${ }^{98} \mathrm{He}$ also hoped to create the opportunity for an encounter with representatives of Jewish politics and culture and to discuss with them the toughest questions related to the presence of converts in Israeli society. It is clear, therefore, that the proposal for a Jewish-Christian dialogue also necessarily entailed unprecedented and significant historicalpolitical problems: not only was the relationship between the two faiths under discussion, but also the Catholic attitude toward the State of Israel, which was moving away from its broad-stroke hostility toward the Jewish nationalist movement's philo-Zionist orientation.

From the time of its establishment, two fundamental tensions animated the association. In the first place was the reconsideration of Jewish-Christian relations: this was not only aimed at promoting a generic interreligious dialogue but constituted the desire to create a new community (kehilah), inspired by the Judeo-Christian example and especially by the ASJ interpretation of the way of life described in the Acts of the Apostles (2:42-47). There was explicit

96 APNDS, P. Stiassny, document titled "Idées pour notre chaliah," undated (ca. 1956), translation from French. The term shaliah mentioned in the text indicates the envoy or representative. This is the word used in the Bible to refer to an apostle. Jerusalem, September 8, 1954, translation from French. The Pauline reference is 1 Corinthians 9:20. 
reference to this; for example, when the local committee for Tel Aviv was formed, it was established that the members should follow "the example of the first Christians" and, in particular, would contribute a percentage of their monthly income to the community chest. ${ }^{99}$ The ASJ members thus proposed to return to the origins of Christianity and, in particular, to its Jewish roots; the community which they outlined, and especially the case of the foyers and the Christian kibbutzim, retraced distinctive features of the first church that formed around the apostles after the death of Jesus. These characteristics earnest prayer, sharing resources in common, responding to the needs of those in distress - were reintroduced as foundational elements and goals for the association. It is clear how their studies in Judeo-Christianity influenced this elaboration, with an idealized representation of the origins of Christianity also part of the picture. However, the concrete realization of this cherished ideal would not proceed without tensions and conflicts. After a long discussion on the association's economic management, it was decided that the money gathered by each group in the various cities should be left at the disposal of individual committees and not be pooled among all the association's members.

All these considerations led to a second point. The much-desired construction of a Judeo-Christian identity to be applied to the converted Jews did not only signify an anachronistic repurposing of the past: political reflection on the present time, especially in the light of the foundation of the State of Israel, was highly salient among the association's founders. The consideration of this event as a historical fact was one of the elements that marked a new turn and a break between the association and other contemporary groups advocating Judeo-Christian friendship. ${ }^{100}$ Stiassny was particularly conscious of the political implications inherent in the patriarchal group's desire to reconstruct a Judeo-Christian model: aside from the "necessity of returning to the living sources of the religion ... is there any more original revitalization than that which is realized by a part that is qualitatively important to the Jewish people,

99 AOSJ, 1945-1959, minutes of the foundational meeting of the local committee of Tel Aviv, January 31, 1956, translation from French.

100 From its foundation, the association questioned "Israel as a historical fact, the continuity of its existence in the history of humanity: before and after Christ and during the history of the Church - up until modern times, considering in the same way concerning the existence of Israel, how the people have newly returned to their country of origin, and have made their appearance in history and on the global political stage as a Nation, constituted as a State." AOSJ, 1945-1959, report titled "Projet schématique pour une publication périodique sur Israël," Jerusalem, November 12, 1954, translation from French. 
making a return to the Land of Israel?" he asked. ${ }^{101}$ This historical fact was the realization of the Zionist project in the foundation of the State of Israel. As the founders of the association saw it, this was an extraordinarily significant event both politically and religiously, for it signified the "return from exile" for the Jews, but it was also important for the Catholic Church and in particular for the Jewish converts to Christianity in Israel. ${ }^{102}$ The establishment of Israel was now seen as one of the "signs of the times": for most members of the association, the realization of a state for the Jews was a historic new page in the book of the mystery of Israel. No attempt was made to ascribe the foundation of Israel to divine right or to adopt a Zionist Catholic perspective similar to the Protestant version. It was most important to offer a contrast to the Catholic rejection - including that of the Holy See - of the State of Israel and to assign the events of May 1948 to a new chapter in Jewish-Christian relations: for the members of the association, the foundation of Israel was now a component in dispelling the mystery of Israel in the history of salvation. This stage was mysterious in itself: the association's founders did not ascribe a uniform significance to the establishment of the Israeli state, nor did they believe that they knew and understood all its political and religious implications. In any case, their reflections aimed to mark a break with traditional interpretations offered in the Catholic arena and to signal the first step in a new phase of relations between Jews and Christians.

In the context of the communities of Christians of Jewish origin in Jerusalem, Jaffa, Haifa, Beersheba and the other centers in Israel, the association's members developed an awareness of their own unconditional, albeit problematic loyalty to the State of Israel, a state whose Jewish character was as fundamental as it was disputed. This translated into a dual affiliation, as affirmed several times in the writings of various members of the association: first, the love of biblical Israel and the profession of a new awareness for all Christians and for the Catholic Church in particular, of Romans 9-11 (and the Maritainian interpretation of these chapters). There was the grounds for the necessity to reestablish the ecclesiastical self-consciousness with respect to

101 "Are we not in the presence of a new fact in the history of salvation, a fact which enters history and simultaneously reorders it?," in Joseph Stiassny, "Le problème religieux en Israël (1956)," in Recueil en hommage à Joseph Stiassny, ed. Elio Passeto (Jerusalem: Religieux de Notre-Dame de Sion, 2007), 4, translation from French.

102 In 1955, Jean-Roger Héné wrote that "the unique historical fact of the restoration of the State of Israel is of great significance for the Catholic Church and ... the small group of Catholic Jews in Israel is urgently in need of being supported and sustained by the whole Church". AAAJ, R 80, Jean-Roger Héné, CEuvre St Jacques 2, document on an initiative by the Dutch Catholics in support of the ASJ, undated (ca. late 1955). 
the Jewish world, with the latter representing the basis for reestablishing ecclesiastical self-consciousness itself, in the conviction that the mystery of Israel was an integral part of the theological identity of the church. In second place was the link with historical Israel as realized in the state that came into being in 1948, and whose full political legitimacy the association upheld. Hussar's and Leroy's requests to receive Israeli citizenship were not only a response to the need for a practical solution to the problems relating to the periodic need to renew visitor's visas. Much more profoundly, it signified their commitment to a political project - Zionism - and affirmed the need for the church to acknowledge Israel's statehood not just from the perspective of international relations, but theologically as well. It also implied constant awareness of the danger that criticism of Israel could conceal underlying motives and prejudices that were anti-Jewish and antisemitic in character. For the kehilah, the State of Israel, being only a few years old, still had to take stock of numerous questions and should not therefore be judged hastily. In the difficult construction of a Jewish identity in the period after the Shoah, and in the light of the foundation of Israel, ${ }^{103}$ the members of the association identified themselves as modern Judeo-Christians, loyal to the Catholic Church and to the new State of Israel.

The positions expressed by the ASJ on all these topics were not univocal and monolithic; if there was substantial agreement among the members on these issues, there were also differences within the association. The most significant were those relating to the evaluations of Zionism, specifically whether it was an ideology or a project historically realized in the foundation of the State of Israel. The members generally shared a profound fascination with Zionism and its evolution; in their eyes, the new state was the expression of a "miracle", the product of resourceful pioneers capable of transforming a desert area into a flourishing landscape. The "return to Zion" had a mystical ring to it, corresponding to the mystery of Israel, but it was not the subject of an

103 See Joel Peters and Rob Geist Pinfold, eds., Understanding Israel: Political, Societal and Security Challenges (New York: Routledge, 2019); Alain Dieckhoff, "Nationalisme et religion en Israël," in L'enjeu mondial: Religion et politique, ed. Alain Dieckhoff and Philippe Portier (Paris: Presses de Sciences Po, 2017), 117-27; David Tal, ed., Israeli Identity: Between Orient and Occident (New York: Routledge, 2013); Eliezer Ben-Rafael, Yosef Gorny, and Yaakov Ro'i, eds., Contemporary Jewries: Convergence and Divergence (Leiden: Brill, 2012); Dieckhoff, "Israël: la pluralisation de l'identité nationale," in Nationalismes en mutation en Méditerranée orientale, ed. Alain Dieckhoff and Riva Kastoryano (Paris: CNRS, 2002); and Naftali Rothenberg and Eliezer Schweid, eds., Jewish Identity in Modern Israel: Proceedings on Secular Judaism and Democracy (Jerusalem: Van Leer Jerusalem Institute; Urim, 2002); Yosef Gorny, The State of Israel in Jewish Public Thought: The Quest for Collective Identity (New York: New York University Press, 1994). 
apocalyptic-messianic vision like that maintained by the movements that supported Christian Zionism. For the association's members, the foundation of Israel did not imply the imminent coming of Christ and the end of times. For this reason, too, there was no wish to drive conversionist activities in the direction of accelerating the adherence to Christianity within Israel.

The association's documents from its foundation years do not contain any examination of the various currents that comprised the Jewish nationalist movement, even if perhaps this kind of understanding was not lacking in the meetings dedicated entirely to Zionism that were held in the Saint Simeon foyer in the mid-195os. The association's members maintained a critical view of certain measures taken by the Israeli government, especially regarding the status of the Arab population as well as of the new Jewish immigrants from Eastern Europe. For all these reasons, in the first phase at least, the expression "Catholic Zionism" should perhaps be replaced with "philo-Zionism" to describe the political position of various members of the kehilah. ${ }^{104}$ Then, in the decades that followed, the orientation of some of the association's founders shifted toward a more emphatic support for Israeli policies and the embracing of Zionism, as in Hussar's case.

From its beginnings, the ASJ was a laboratory within which a new identity was defined and molded: that of Jewish Israeli Christians. With this combination, the members of the association acknowledged themselves as Jewish converts to Christianity who wished to conserve their Jewish origins. The association, then, is not to be confused with Messianic Jews - Jews who acknowledged Jesus as the Messiah, placing them halfway between affiliation to Judaism and to Protestantism. ${ }^{105}$ The association emerged and developed within the Catholic Church and remained attached to it. The Christian identity

104 The only one who wrote openly about Catholic Zionism during this phase was John Friedman (1916-99). In 1947, the year in which he entered the Carmelite order and took the name of Elias, he published a volume titled The Redemption of Israel (New York: Sheed and Ward, 1947), in which the young Jewish South African convert to Christianity prefigured the foundation of Israel as a necessary "solution to the Jewish question", which, however, should be joined with the conversion of the Jews to Catholicism. For Friedman, Jewish history was demarcated by three great exiles: the Egyptian, the Babylonian and that of the Diaspora, which would only end with the embrace of the Catholic faith. To this end, Zionism too would have to be transformed into "Catholic Zionism" (115-17). Upon his arrival in Israel, Friedman participated in the AsJ for several years, but later distanced himself from it and founded a new group called the Association of Hebrew Catholics.

105 See David Rudolph and Joel Willitts, eds., Introduction to Messianic Judaism: Its Ecclesial Context and Biblical Foundations (Grand Rapids, MI: Zondervan, 2013); and Edward Kessler, "Messianic Jews," in A Dictionary of Jewish-Christian Relations, ed. Edward Kessler and Neil Wenborn (Cambridge: Cambridge University Press, 2005). 
predominated over the Jewish component, even in the desire to form a community that demonstrated the need for the church to take account of its own Jewish roots.

The association's origins embodied the will to open up a movement in the church that would propagate the recognition of Judaism as the basis of Christianity, striving to overcome the long history of Catholic prejudice against and rejection of the Jews. Within the Latin Church of Jerusalem, AsJ members presented themselves and strove to be frontaliers, bridges of contact between the two communities. ${ }^{106}$ This characteristic of affiliation with two communities - the one of origin and the one of choice - is in the nature of the convert, while at the same time he never fully identifies with either one. In the case of the ASJ, the designation Jewish Christians precisely signifies this hope, this utopia, of linking the two communities, Jewish and Catholic, that were historically implicitly conjoined and were radically divided at the present time. The search for a space, for a foyer or a Christian kibbutz, also seems indebted to the need to inhabit a place that could give form to the utopia, the no-place, in which they were really situated, bridging one and the other faith without being fully recognizable in one or the other camp. The claimed affiliation to the State of Israel acquired an additional complexity in this already complex picture. All these aspects that appeared in embryonic form at the foundation of the AsJ community became manifest over time.

Certainly, in the construction of the identity of the association's members as Jewish Israeli Christians, the common choice and the question of adherence to Zionism were not the only elements at play; to these should be added reflections on the liturgy in the direction of Catholic worship in Hebrew, which constituted one of the areas in which the ASJ's founders were most committed ever since its establishment.

\subsection{The Path to a Hebrew Liturgy}

The question "how to pray?" has surfaced throughout the history of the AsJ. Since its foundation, its members gathered for spiritual retreats, especially at the most important points in the liturgical year. ${ }^{107}$ Acknowledgment of the central role of the liturgy in the life of the ASJ and the conviction that the

\footnotetext{
106 See Connelly, From Enemy to Brother, 63-64.

107 See, for example, the documentation on the retreat held with the Sisters of Notre-Dame de Sion at the community of Saint John in the Wilderness at 'Ayn Karim in Holy Week 1957, contained in ASNDS, St Jean in Montana, Eglise en Israël, 1949-1964, "Qehila". The chronicles of the St John in the Wilderness convent mention the first AJS retreat at 'Ayn Karim on June 15-16, 1955. ASNDS, ibid., Journal de la maison de St Jean du ter septembre 1954 au 15 octobre 1955 .
} 
heart of the nascent community of faithful could be found in prayer, according to the ancient principle of lex orandi, lex credendi (the content of prayer is also the content of the faith), led the members of the association to devote special attention to the question of what liturgy to adopt. Prayer and song in Hebrew were part of the community's life since its foundation. ${ }^{108}$ The debate as to what rite and language to choose for the new community, and the subsequent issue of translating the missal, carried out both internally and between Jerusalem and Rome, dealt with delicate questions that went beyond their liturgical context and brought other issues in their train.

Two principal questions emerged. The first revolved around the issue of how the ASJ community would be able to replicate and accept as their own certain prayers containing formulations and expressions that were imbued - historically and theologically - with styles and propositions that were hostile to the Jews or were markedly anti-Jewish. The case of the invocation recited within the so-called "universal prayer" on Good Friday (and particularly the two passages "oremus et pro perfidis judaeis" and the reference to "judaicam perfidiam") is the most obvious. At the first Easter celebrated together by members of the association at 'Ayn Karim, Leroy recited this passage hastily, trying not to draw attention to it, but in truth revealing the extent of the embarrassment and difficulty for the young community of converts and Christians of Jewish origin in repeating prayers describing the Jews as perfidi. ${ }^{109}$

This problem was not confined to the Latin Catholic liturgy. The studies begun by Leroy and other founders of the ASJ found that the modes and prejudices of Christian anti-Judaism were also present in the Eastern Catholic liturgy, especially in the Eastern Syriac rite that was initially identified as the most suitable for the new community to follow in its prayer. Thus arose the need to rethink the liturgy in order to overcome this tradition - at least in part - by proposing novel solutions which, in any case, would not place them outside of the bounds of liturgical experimentation as permissible and authorized by the Holy See.

The need to research and attempt new formulations while remaining within the Latin Patriarchate gave rise to the second question. The tricky

108 AOSJ, 1945-1959, "Tfilat ha-Mishpahah be-yame ha-Tsipiyah" [Family prayer during Advent] and the sheet music and words of various prayers and songs composed between 1955 and 1957: "Shir Miriyam, Romema Nafshi" [Song of Mary, My Soul Will Exalt, Magnificat]; "Shalom lakh" [Ave Maria]; "Shir le-Hag ha-Molad: Yeshua yish`enu" [A song for Christmas: Jesus will save us]; "Be-Derekh yisurekha" [On the path]; "Bo na, ruah ha-ḳodesh ha-bore" [Veni creator]; "Matai yavo ha-Mashiah?" [When will the Messiah come?].

109 See Maria Paiano, "Il dibattito sui riflessi dell'antisemitismo nella liturgia cattolica," Studi storici 41 , no. 3 (2000). 
integration of the ASJ within the life of the Jerusalem Latin Church due to the preexisting separation between the Arab Catholics and those of Jewish origin was in danger of becoming even more complicated thanks to liturgical differentiation. Would substituting the Latin rite with a liturgy closer to the sensibilities and life of the Jewish-Catholic community spell a split in the Latin Church? The responsible members of the association answered in the negative; one of the association's goals was to overcome the breach between Arab Catholics and those of Jewish origin within the patriarchal diocese of Jerusalem that had arisen as a result of the conflict. At the same time, according to the association's founders, this did not mean renouncing the "dream" of a Jewish church in Israel that could form a bridge to the Arab Latin community as well as to other Catholic communities that followed the Eastern rites.

From a historical perspective, the effort to create a liturgy that would gradually incorporate prayers or even entire sections in Hebrew had already been underway since the foundation of the State of Israel. In 1948, the clergy of Notre-Dame de Sion in Jerusalem translated the Credo into Hebrew. The Little Brothers of Jesus were also heavily engaged and active on the liturgical front. In 1954, in discussing the possibility of founding a community in Israel, Prior General Voillaume and Cardinal Tisserant expected that Mass would be celebrated in Israel following neither the Latin nor the Byzantine rite, but with a Semitic rite such as the Syriac, in Aramaic. Furthermore, the secretary of the Oriental Congregation had tasked Voillaume with reporting to Leroy that he had been studying Syriac, suggesting the possibility of translating some passages of the missal into Hebrew.

These recommendations were put together in Tisserant's authorization, dated autumn 1955, for Voillaume to found a fraternity of the Little Brothers in Israel, ${ }^{110}$ connecting it explicitly to the AsJ; the new community was required to cooperate with the ASJ and to help it take its first steps. The secretary of the Congregation for the Oriental Church also allowed for the future community of Little Brothers to use the Syriac rite, thus placing it under the jurisdiction of the Syrian patriarch of Antioch, Cardinal Ignatius Gabriel Tappouni. Elsewhere, the community of Little Sisters of Jesus led by Sr. Magdeleine had already opened a fraternity in Israel, but this followed the Byzantine rite. The experiment with the Syriac rite on the part of the Little Brothers responded to the desire to check the possibility that the community of Christians of Jewish origin could use this rite for their liturgical celebration. Both in France and even after his arrival in Israel, the Little Brother Leroy studied the Syriac rite and its suitability for the liturgy of the young community.

110 See AVIPLJ, Opera San Giacomo, Tappouni to Gori, Beirut, December 15, 1955. 
During 1955, Leroy met with Tisserant, who further encouraged him to work on a translation of the Mass, while also conceding that the breviary could be read in Hebrew. The Little Brothers of Jesus allowed praying with the Syriac Antiochian rite for three years. Leroy studied the Syriac liturgy attentively, recited the office of prayers and the Mass according to the Syriac rite, and sought counsel and opinions in Israel and France. After a year and a half, at the invitation of Apostolic Delegate Oddi and Prior General Voillaume, Leroy sent his reflections to Tisserant. ${ }^{111}$ He reported that he had proceeded with the translation into Hebrew of parts of the Syriac Mass that were recited aloud in Arabic or Malabari, which had then been reviewed by Stiassny and Tournay of the École biblique et archéologique. The resulting Mass was then proposed to the AsJ and other Jewish Christians in Israel, who received this new liturgy very positively, even preferring it to the Byzantine rite.

If the features of a rite from the Semitic area such as the Syriac, with its frequent references to the Old Testament, might recommend its selection, Leroy did not omit to underline that the "modern and Western" Jewish world was by now alienated from some categories of thought peculiar to the biblical Jewish system. Furthermore, he acknowledged that the hierarchy of the Syriac rite was composed of Arabs who, even if "they were very well intentioned", were part of the state that was at war with Israel, and that, in particular, there were passages with a strongly antisemitic tone in the Office and the missal that made a decision in favor of the Syriac rite impossible. The Latin rite, despite its various limitations, was already in use among Jewish Catholics in Israel and, according to Leroy, had less political complications.

After analyzing Leroy's considerations, Tisserant accepted the concerns about the unsuitability of an Aramaic rite for the Jewish Christians. Despite Oddi's disagreement, ${ }^{112}$ the secretary of the Congregation for the Oriental Church authorized some AsJ members "to translate the Latin Mass into Biblical Hebrew from the beginning up to the Offertory, which was excluded". Tisserant

111 AOSJ, 1945-1959, “Compte-rendu sur l'emploi du rite syrien d'Antioche en Israël," Leroy to Tisserant, Jerusalem, Jaffa, June 1956. Leroy sent a copy of this text also to Oddi. See AAV, $A D A G P, 20,81,5$, fols. 331-33, July 5, 1956.

112 The apostolic delegate met Leroy, whose "linguistic knowledge and supernatural spirit" made an "excellent impression" on him. However, Oddi considered that in his "humble and subordinate opinion it is a mistake to introduce a new liturgy in the Middle East, which already has many liturgies, perhaps too many!". AAV, ADAGP, ibid., fols. 327-30: 328 , Oddi to Tisserant, copy, Jerusalem, April 9, 1956, translation from Italian. 
requested a translation that was correct "from the linguistic rather than the dogmatic standpoint". 113

Tisserant's decision was the first important indication of the attention Rome was paying to the little group of Jewish Christians in Israel. The authorization of a partial vernacularization of the missal opened the way to a Hebrew liturgy within the Latin Church of Jerusalem and anticipated the conciliar liturgical reform some years later. The liturgy would constitute one of the most significant elements in the formation of the identity of the fledgling community and in the subsequent history of the ASJ.

11 AOSJ, 1945-1959, Tisserant to Voillaume, Rome, February 15, 1957, translation from French. See also AVI PLJ, Opera San Giacomo, Vergani to Gori, Haifa, March 19, 1957. 